4

MCE Special Edition: Animal Models of Endocrine Neoplasia

\title{
GATA factors in endocrine neoplasia
}

\author{
Marjut Pihlajoki, ${ }^{1}$ Anniina Färkkilä, ${ }^{1,2}$ Tea Soini, ${ }^{1}$ \\ Markku Heikinheimo, ${ }^{1,3}$ and David B. Wilson ${ }^{3,4}$
}

\author{
${ }^{1}$ University of Helsinki and Helsinki University Central Hospital, Children's Hospital, \\ 00290 Helsinki, Finland \\ ${ }^{2}$ University of Helsinki and Helsinki University Central Hospital, Department of Obstetrics and \\ Gynecology, 00290 Helsinki, Finland \\ ${ }^{3}$ Department of Pediatrics, Washington University School of Medicine, \\ St. Louis Children's Hospital, St. Louis, MO 63110 USA \\ ${ }^{4}$ Department of Development al Biology, Washington University School of Medicine,
}

St. Louis Children's Hospital, St. Louis, MO 63110 USA

Running title: GATA factors in endocrine neoplasia

Keywords: adrenocortical tumor, granulosa cell tumor, parathyroid tumor, pituitary adenoma, SertoliLeydig cell tumor

Address correspondence and reprint requests to: David B. Wilson MD, $\mathrm{PhD}$, Box 8208, Washington University School of Medicine, 660 S. Euclid Ave., St. Louis, MO 63110, USA. Phone: +1.314.286.2834. FAX: +1.314.286.2892. Email: wilson_d@wustl.edu

Disclosure summary: The authors have nothing to disclose.

Word count $=6832$. Table count $=5$. Figure count $=7$. Graphical abstract $=$ none 

44 models are highlighted.

45

\section{Abstract}

Word count: 187
GATA transcription factors are structurally-related zinc finger proteins that recognize the consensus DNA sequence WGATAA (the GATA motif), an essential cis-acting element in the promoters and enhancers of many genes. These transcription factors regulate cell fate specification and differentiation in a wide array of tissues. As demonstrated by genetic analyses of mice and humans, GATA factors play pivotal roles in the development, homeostasis, and function of several endocrine organs including the adrenal cortex, ovary, pancreas, parathyroid, pituitary, and testis. Additionally, GATA factors have been shown to be mutated, overexpressed, or underexpressed in a variety of endocrine tumors (e.g., adrenocortical neoplasms, parathyroid tumors, pituitary adenomas, and sex cord stromal tumors). Emerging evidence suggests that GATA factors play a direct role in the initiation, proliferation, or propagation of certain endocrine tumors via modulation of key developmental signaling pathways implicated in oncogenesis, such as the WNT/ $\beta$-catenin and TGF $\beta$ pathways. Altered expression or function of GATA factors can also affect the metabolism, ploidy, and invasiveness of tumor cells. This article provides an overview of the role of GATA factors in endocrine neoplasms. Relevant animal 


\section{Overview of GATA factors in development and disease}

\subsection{Members of the vertebrate GATA family}

By regulating cell fate specification and differentiation, GATA transcription factors play important roles in eukaryotic development. The vertebrate GATA family comprises six members (GATA1-6) named in order of discovery (Patient and McGhee, 2002). All bind to the consensus DNA element, WGATAA, known as the GATA motif (Bresnick et al., 2012). With the exception of Gata5, homozygous null mutations in genes encoding GATA family members result in embryonic lethality in mice, underscoring the vital roles that these transcription factors play in development [reviewed in (Molkentin, 2000; Viger et al., 2008)]. Human diseases associated with germline loss-of-function mutations in GATA factors are summarized in Table 1.

All vertebrate GATA proteins contain a pair of conserved zinc finger domains (Patient and McGhee, 2002). The C-terminal finger is essential for DNA binding, whereas the N-terminal finger physically interacts with other transcriptional regulators such as the "Friend of GATA" factors FOG1 (ZFPM1) and FOG2 (ZFPM2) (Bresnick et al., 2012). GATA motifs are common in the genomes of vertebrates, but global chromatin immunoprecipitation studies in various cell types suggest that GATA factors occupy less than 1\% of the consensus sites (Bresnick et al., 2012). This implies the existence of mechanisms that discriminate among these abundant motifs.

GATA factors can act as either transcriptional activators or repressors depending on the context (Viger et al., 2008). Although all GATA factors bind to the same DNA element, there is surprisingly little functional redundancy among these proteins (Zheng and Blobel, 2010). Individual GATA factors elicit distinctive functions through cooperative interactions with other transcriptional regulators. Functional diversity is also achieved via post-translational modifications (e.g., phosphorylation, acetylation, and sumoylation) that alter the intrinsic activity of different GATA factors (Viger et al., 2008). During the differentiation of a particular lineage, a GATA motif in the promoter/enhancer of a gene may be occupied sequentially by more than one GATA factor. For example, as erythroid progenitors 
mature the stem cell factor GATA2 is displaced from specific sites by the terminal differentiation factor GATA1, a phenomenon termed a "GATA switch" (Bresnick et al., 2010). A similar switch is presumed to occur in intestinal epithelium, where GATA6 maintains stem/progenitor cells and GATA4 promotes terminal differentiation into mature enterocytes (Beuling et al., 2011). GATA switches are often associated with altered transcriptional output, emphasizing that different GATA factors can exert distinct functions at the same binding site (Bresnick et al., 2012). GATA switches occur not only during normal development but also in disease states, such as endometriosis. The transformation of endometrial stroma into endometriotic stroma is accompanied by an epigenetically-mediated switch from expression of GATA2 to GATA6 (Dyson et al., 2014).

\subsection{GATA factors as tumor markers}

Since GATA factors regulate genetic networks that can expand stem/progenitor cell populations or drive differentiation, it comes as no surprise that alterations in the expression or function of GATA factors have been linked to neoplastic transformation. Indeed, GATA factor genes have been shown to be mutated, overexpressed, or underexpressed in a wide range of solid tumors and leukemias [reviewed in (Ayanbule et al., 2011; Bresnick et al., 2012; Viger et al., 2008; Zheng and Blobel, 2010)].

GATA factors can serve as tumor markers that shed light on the developmental origins, clinical behavior, and pathogenesis of certain neoplasms, as illustrated by studies of GATA3 in breast cancer and GATA2 in prostate cancer. GATA3 is abundantly expressed in luminal cells of the mammary epithelium but not their multipotential progenitors (Chou et al., 2010). Conditional deletion studies in the mouse have shown that Gata3 is required for branching morphogenesis and terminal differentiation of luminal epithelial cells [reviewed in (Chou et al., 2010; Zheng and Blobel, 2010)]. Interestingly, loss of Gata3 in adult mammary epithelium triggers de-differentiation of luminal cells, increased cell proliferation, and disorganization of ducts, features reminiscent of neoplastic transformation. In primary breast tumors low or absent GATA3 expression is associated with shorter patient survival and a host of negative prognostic indicators (primary tumor size, lymph node metastases, lack of estrogen receptor and progesterone 
101 receptor expression, etc.) (Chou et al., 2010). GATA2 is expressed in both benign prostatic epithelium

102 and prostate cancer, but levels of GATA2 are significantly higher in the latter and correlate with the risk 103 of cancer progression and metastasis (He et al., 2014). Androgen receptor (AR) signaling is a key driver 104 of prostate cancer, and GATA2 has emerged as a critical regulator of AR expression and activity in this 105 malignancy (Chiang et al., 2014; He et al., 2014; Wu et al., 2014).

\subsection{GATA factors interface with signaling pathways involved in both normal development and} tumorigenesis

Signaling pathways that control stem cell self-renewal, terminal differentiation, and cell survival, such as the WNT/ $\beta$-catenin and TGF $\beta$ pathways, are often co-opted during tumorigenesis. GATA factors

111 have been shown to interface with developmental signaling pathways implicated in oncogenesis, as

112 evidenced by studies of GATA6 in colorectal tumors. Constitutive activation of WNT/ $\beta$-catenin signaling

113 and inhibition of bone morphogenetic protein (BMP) signaling are the principal genetic alterations

114 associated with colorectal tumor formation (Whissell et al., 2014). GATA6 plays a key role in colorectal

115 tumorigenesis by driving expression of $L G R 5$, which enhances WNT/ $\beta$-catenin signaling and enables

116 tumor stem cell renewal, and by inhibiting expression of BMPs, which promote terminal differentiation

117 (Tsuji et al., 2014; Whissell et al., 2014). GATA factors have also been shown to regulate genes involved 118 in apoptosis of normal and tumor cells. For example, GATA4 has been shown to protect cardiomyocytes 119 from doxorubicin-induced apoptosis by upregulating anti-apoptotic members of the BCL2 protein family 120 (Aries et al., 2004; Kobayashi et al., 2010) and to protect ovarian tumor cells from an extrinsic apoptosis 121 inducing ligand TRAIL (Kyrönlahti et al., 2010) (see Section 2.2).

\subsection{GATA factor dysregulation can affect tumor cell migration, invasiveness, and ploidy} GATA factor dysregulation can impact tumor cell biology in other ways. In breast cancer cells

125 GATA3 promotes differentiation, limits cell migration, and suppresses metastasis by inducing expression 126 of a microRNA (miR-29b) that downregulates expression of genes involved in angiogenesis, collagen 
127 remodeling, and proteolysis (Chou et al., 2013). Ovarian carcinomas are thought to arise from ovarian

128 surface (germinal) epithelium or neighboring oviduct epithelium (Nezhat et al., 2015). Approximately

$12950 \%$ of ovarian carcinomas lack GATA6 expression entirely, and an additional $40 \%$ show abnormal

130 GATA6 immunostaining that is either weak or cytoplasmic rather than nuclear (Cai et al., 2009). Loss of

131 GATA6 in germinal epithelial cells triggers their de-differentiation, manifested as the loss of expression 132 of proteins required for epithelial organization (Cai et al., 2009; Capo-chichi et al., 2011; Capo-chichi et

133 al., 2009). Loss of GATA6 expression in these cells also leads to deformation of the nuclear envelop and a

134 failure of cytokinesis, resulting in aneuploidy (Capo-chichi et al., 2009). The link between GATA6

135 deficiency and aneuploidy appears to be a generalized phenomenon, because mouse peritoneal

136 macrophages lacking Gata6 expression also exhibit changes in ploidy along with metabolic derangements

137 (Gautier et al., 2014; Rosas et al., 2014).

138

139

\subsection{Focus of this article}

This article reviews the role of GATA factors in neoplasias of various endocrine tissues. The

141 expression patterns of GATA factors in developing endocrine organs and in their corresponding

142 neoplasms are described. The use of GATA factors as endocrine tumor markers in both preclinical and

143 clinical settings is discussed. Relevant animal models, such as the mouse, ferret, dog, and goat, are

144 highlighted. Endocrine-related tumors, such as breast and prostate cancer, are not a focus of this review.

145 Dozens of putative GATA target genes have been identified in endocrine tissues. Unfortunately,

146 space constraints do not allow us to cite all the original research papers characterizing these target genes.

147 Instead, the reader is referred to review articles that summarize GATA target genes in endocrine tissues

148 (LaVoie, 2003; Röhrig et al., 2014; Tevosian, 2014; Viger et al., 2008).

\section{Ovarian neoplasms}


GATA4 and GATA6 are the predominant GATA factors expressed in the developing ovary (Fig 1) (LaVoie, 2014; Viger et al., 2008). At embryonic day (E) 10.5 in the mouse, Gata4 expression is evident in the genital ridge (Hu et al., 2013), and by E13.5 GATA4 is found in most ovarian somatic cells (Anttonen et al., 2003; Efimenko et al., 2013; Heikinheimo et al., 1997; Kyrönlahti et al., 2011b). In the adult ovary, GATA4 is present in theca cells and in granulosa cells of primary, preantral, and antral 158 follicles, but not in primordial follicles or luteal cells (LaVoie et al., 2004; Viger et al., 2008). Like

159 Gata4, Gata6 is expressed in somatic cells of the prenatal ovary and in theca and granulosa cells of large 160 follicles in the adult ovary; however, in contrast to Gata4, Gata6 is expressed in corpora lutea 161 (Heikinheimo et al., 1997; Miyamoto et al., 2008). Both GATA4 and GATA6 are found in ovarian 162 surface epithelium (Capo-chichi et al., 2003). Ovarian expression of GATA factors is controlled by an array of endocrine and paracrine factors, 164 including gonadotropins and members of the TGF $\beta$ superfamily [reviewed in (Viger et al., 2008)]. For 165 example, treatment of juvenile mice with eCG enhances follicular expression of Gata4 and Gata6 (Heikinheimo et al., 1997), while treatment of cultured preovulatory human granulosa cells with hCG

167 upregulates GATA6 expression (Laitinen et al., 2000). In granulosa cell tumors, TGF $\beta$ treatment 168 increases GATA4 levels (Anttonen et al., 2006). In ovarian somatic cells and other endocrine tissues, 169 GATA factors serve to integrate input from signaling pathways including the cyclic AMP/protein kinase 170 A (cAMP/PKA) and mitogen-activated protein kinase (MAPK) pathways [reviewed in (Viger et al., 171 2008)]. Activation of these two signaling pathways in gonadal cells results in phosphorylation of GATA4 172 at distinctive sites that mediate synergistic interactions with other transcriptional regulators [reviewed in 173 (Viger et al., 2008)]. Promoter analyses have identified a number of GATA-dependent genes in ovarian 174 steroidogenic cells, including Star, Cyp1 1a1, Cyp19a1, Hsd17b1, and Inha [reviewed in (Viger et al., 175 2008)]. Targeted mutagenesis studies in the mouse have delineated the importance of Gata4 and Gata6 in 176 follicular development and ovarian function (Table 2) [reviewed in (Tevosian, 2014)]. 
Granulosa cell tumors (GCTs), the most common sex-cord stromal tumors, are subclassified in

180 two forms: an adult-type (AGCT), that typically occurs in perimenopausal women, and a rare juvenile

181 form that affects mostly children and adolescents (Schumer and Cannistra, 2003). GCTs are

182 steroidogenically active and can cause precocious puberty, disturbances in the menstrual cycle, and

183 endometrial hyperplasia (Jamieson and Fuller, 2012; Schumer and Cannistra, 2003).

184 AGCTs retain the biological features of normal proliferating granulosa cells of preovulatory

185 follicles (Fuller et al., 2002). Thus, the molecular pathogenesis of AGCT is hypothesized to entail

186 disrupted expression of signaling pathways that regulate granulosa cell proliferation and apoptosis. A

187 somatic missense mutation (p.C134W) in FOXL2, a transcription factor required for normal murine 188 granulosa cell differentiation and ovarian maintenance (Schmidt et al., 2004; Uhlenhaut et al., 2009), is

189 present in $~ 95 \%$ of AGCTs, suggesting that it is pathognomonic for this tumor (Jamieson et al., 2010;

190 Kim et al., 2010b; Shah et al., 2009). In contrast, juvenile GCTs lack the p.C134W mutation (Kalfa et al., 191 2007).

192 Current evidence suggests that a key event in AGCT pathogenesis is a failure of the mutant

193 FOXL2 to form specific protein-protein interactions, leading to subtle changes in the transcription of 194 target genes (L'Hote et al., 2012). Recent studies suggest that GATA4 cooperates with FOXL2 during 195 granulosa cell tumorigenesis (Fig 2). The majority of AGCTs express GATA4 at levels comparable to 196 normal preovulatory granulosa cells (Laitinen et al., 2000), and high GATA4 expression in these tumors 197 predicts both increased risk of recurrence and shorter disease specific survival (Färkkilä et al., 2014). 198 GATA4 expression in AGCTs also correlates with the intrinsic apoptotic pathway inhibitor BCL2 and 199 proproliferative CCND2 expression, suggesting that GATA4 may act as an anti-apoptotic factor in adult 200 AGCTs (Kyrönlahti et al., 2008). GATA4, SMAD3, and FOXL2 physically interact and modulate gene 201 expression, cell viability, and apoptosis in AGCTs (Anttonen et al., 2014). GATA4 is also expressed in 202 juvenile GCTs (Virgone et al., 2012); however, increased expression of GATA4 does not correlate with 203 aggressive behavior as seen in adults. In contrast to GATA4, GATA6 expression in AGCTs is inversely 
204 correlated with tumor size, suggesting that GATA6 may suppress proliferation in this cell type (Anttonen 205 et al., 2005). AGCTs (Table 3). Aberrant expression of GATA factors accompanies tumorigenesis in several of these mouse models. Collectively, these models reinforce the importance of SMADs and GATA factors in the 209 genesis of AGCTs.

\subsection{Sertoli-Leydig cell tumors of the ovary}

212 Sertoli-Leydig cell tumors (STLCs) are rare ovarian sex cord-stromal tumors characterized by 213 proliferation of Sertoli and Leydig cells of varying degrees of differentiation (Zhang et al., 2014). Sertoli 214 cells, not Leydig cells, are thought to constitute the neoplastic component of these tumors (Nouriani et al., 215 2002). The majority of SLCTs are diagnosed in adolescents or young adults. One-third of patients exhibit 216 hyperandrogenic manifestations (acne, male-pattern baldness, etc.) (Zanotti, 2002; Zhang et al., 2014). A 217 small percentage of SLCTs have estrogenic manifestations, such as menometrorrhagia or postmenopausal 218 bleeding.

219 SLCTs are one of the characteristic tumors in the pleuropulmonary blastoma familial tumor 220 predisposition syndrome, which is caused by heterozygous germline mutations in the microRNA 221 maturation gene DICER1 (Schultz et al., 2014). More than half of SLCTs harbor mutations in DICERI

222 (Witkowski et al., 2013). Conditional deletion experiments in mice have established that Dicerl regulates 223 gonadal somatic cell function (Huang and Yao, 2010; Kim et al., 2010a; Lei et al., 2010; Nagaraja et al., 224 2008), but sex cord stromal tumors have not been reported in germline or conditional Dicerl knockout 225 mice.

Based on its established role in testicular somatic cell differentiation (see section 3.1), GATA4 is

227 hypothesized to have a role in pathogenesis of ovarian SLCTs. A series of studies have shown that 228 GATA4 and its cofactor FOG2 are expressed in some but not all SLCTs (Ketola et al., 2000; Mosbech et 
al., 2014; Siltanen et al., 1999; Virgone et al., 2012). Currently, however, there is no genetic or epigenetic 230 data linking altered expression or function of GATA factors to SLCTs.

\subsection{Thecoma-fibroma tumors of the ovary}

Thecoma-fibroma is a group of benign ovarian sex cord-stromal tumors. These rare neoplasms are composed of varying amounts of theca cells and fibroblasts (Chen et al., 2003). This group of tumors

235 is subdivided into three categories: 1) thecoma, containing lipid-laden theca cells without fibroblasts, 2)

236 thecoma-fibroma, containing both theca cells and fibroblasts, and 3) fibroma, composed almost entirely 237 of fibroblasts. These tumors can occur at any age, but menopausal and postmenopausal women account 238 for most of the cases (Chen et al., 2003). Patients typically present with an abdominal mass and attendant 239 pain; functional tumors may be associated with irregular menstrual bleeding.

Young women with Gorlin (nevoid basal cell carcinoma) syndrome, a tumor predisposition

241 disorder associated with excessive hedgehog signaling due to heterozygous mutations in PTCH1, develop

242 bilateral ovarian fibromas (Morse et al., 2011). One boy with Gorlin syndrome and a testicular thecoma-

243 fibroma has been reported (Ueda et al., 2010). Loss of heterozygosity at 9q22.3, which harbors the

244 PTCH1 gene, is observed in $40 \%$ of sporadic ovarian thecoma-fibroma cases (Tsuji et al., 2005),

245 supporting a pathogenic association between aberrant hedgehog signaling and thecoma-fibroma

246 development. Abundant expression of GATA4 and its cofactor FOG2 have been reported in two pediatric

247 cases of thecoma-fibroma, including a case of bilateral ovarian fibroma associated with Gorlin syndrome

248 (Virgone et al., 2012).

\section{Testicular neoplasms}

\subsection{GATA factors implicated in testicular development and function}

During fetal testicular development Gata4 is expressed in Sertoli cells, fetal Leydig cells, and

254 peritubular myoid cells (Table 4) (Bielinska et al., 2007; Mazaud-Guittot et al., 2014). In the adult testis 
Gata4 is expressed in Sertoli cells, Leydig cells, and putative stem Leydig cells (Ketola et al., 2002;

Ketola et al., 1999; Kilcoyne et al., 2014; Landreh et al., 2014; McCoard et al., 2001; Oreal et al., 2002). Like GATA4, GATA6 is found in testicular somatic cells. In the mouse, testicular Gata6 expression begins in Sertoli cells at E14.5 (Robert et al., 2002) and in fetal Leydig cells shortly thereafter (Tevosian, 2014). Postnatally, Sertoli cells continue to express Gata6 through to adulthood (Anttonen et al., 2003; Imai et al., 2004; Ketola et al., 2002; Ketola et al., 1999; Ketola et al., 2003; Oreal et al., 2002). Gatal is also expressed in mouse Sertoli cells, albeit in a stage-specific manner (stages VI-IX of the seminiferous epithelial cycle) that is dependent on the presence of maturing germ cells (Ketola et al., 2002; Yomogida et al., 1994). Both GATA4 and GATA6 have been detected in adult Leydig cells (Bielinska et al., 2007; Ketola et al., 1999; Ketola et al., 2003), although GATA4 is the predominant GATA factor in this steroidogenic cell type.

Promoter analyses and related studies have identified several groups of putative target genes for GATA4 in testis, including genes associated with sex determination (Sry, Sox9, Dmrt1), peptide hormone production (Inha, Inhb, Amh), gonadotropin signaling (Fshr, Lhcgr), steroid synthesis (Star, Cypl lal, Cyp17a1), and cell-cell interactions (Clmp, Cldn11, Cx30.2) [reviewed in (Tevosian, 2014; Viger et al., 2008). In both Sertoli and Leydig cells, GATA4 activity is modulated via cooperative interactions with other transcriptional regulators/cofactors including SF1, liver receptor homolog 1 (LRH-1/NR5A2), FOG1, and FOG2 [reviewed in (Viger et al., 2008)]. FOG proteins do not bind directly to DNA, but they can function as either enhancers or repressors of GATA transcriptional activity depending on the cell and promoter context studied; on gonadal promoters, however, FOG proteins appear to play a strictly repressive role (Tevosian, 2014). As in ovarian cells, GATA4 is a target for post-translational modifications such as phosphorylation (Tremblay and Viger, 2003; Viger et al., 2008).

Analysis of genetically-engineered mice has shown that interactions between GATA4 and its cofactor, FOG2, regulate the differentiation and function of fetal and adult Sertoli cells [reviewed in (Tevosian, 2014)]. Fog $2^{-/-}$mice and Gata4 ${ }^{k i / k i}$ mice, which bear a knock-in mutation that abrogates the interaction of GATA4 with FOG cofactors, exhibit similar testicular phenotypes including decreased 
testicular Sry expression, aberrant differentiation of Sertoli cells, and sex reversal (Bouma et al., 2007;

282 Manuylov et al., 2007; Tevosian et al., 2002). More recently, conditional mutagenesis studies have shown 283 that functional GATA4 is required for genital ridge development, testis cord morphogenesis, and Sertoli 284 cell function (Hu et al., 2015; Hu et al., 2013; Kyrönlahti et al., 2011a; Manuylov et al., 2011).

The role of GATA4 in Leydig cell development, however, has remained unclear, because gene targeting experiments in mice have not shown a consistent phenotype [reviewed in (Tevosian, 2014)]. For

287 example, Gata4 $4^{-/}$progenitors exhibit an impaired capacity to differentiate into fetal Leydig cells in the 288 testis of chimeric mice (Bielinska et al., 2007). In contrast, conditional ablation of Gata4 in Leydig cells 289 as early as E12.5 does not cause an overt impairment in the expression of Leydig cell differentiation markers in the fetal or adult testis (Manuylov et al., 2011). Interpreting the results of gene targeting experiments in the mouse testis is challenging because of context-dependent effects, compensatory responses, alternative pathways of differentiation, and functional redundancy (Tevosian, 2014). To circumvent these limitations, the impact of Gata4 deficiency on Leydig cell function has been analyzed in

294 less complicated experimental models: two immortalized mouse Leydig tumor cell lines (MA-10, mLTC295 1) and primary cultures of adult mouse Leydig cells (Bergeron et al., 2015; Schrade et al., 2015). Using siRNA and related knockdown approaches, Gata4 deficiency has been shown to have profound effects on 297 specific metabolic pathways, notably steroidogenesis and glycolysis. development in one kindred, although the precise impact of this mutation on somatic cell function is unclear (Lourenco et al., 2011). More recently, mutations in FOG2 have been demonstrated in unrelated 301 individuals with 46,XY gonadal dysgenesis (Bashamboo et al., 2014). Despite the intriguing, stage-specific expression pattern of GATA1 in testis, gene targeting experiments in the mouse suggest that GATA1 is not essential for Sertoli cell function (Lindeboom et al., 304 2003). 
GATA4 expression has been reported in large-cell calcifying Sertoli tumors (LCCSCT), one of the sex cord tumors of testis (Fig 3) (Ketola et al., 2000). LCCSCTs produce estrogen and are associated with gynecomastia and advanced skeletal maturation (Gourgari et al., 2012). Most cases of LCCSCT are

310 sporadic, but about $40 \%$ are associated multiple neoplasia syndromes such as Peutz-Jeghers syndrome

311 (PJS) or Carney complex (CNC). PJS is caused by loss-of-function mutations in the STK11 gene, which

312 inhibit AMP-activated protein kinase, resulting in increased activity of the mammalian target of

313 rapamycin (mTOR) (Gourgari et al., 2012). Dysregulation of the mTOR pathway has been linked to

314 tumorigenesis in various tissues, including endocrine tissues (de Joussineau et al., 2014). CNC is caused

315 by PRKARIA mutations, the gene encoding regulatory subunit type 1 of protein kinase A. This leads to 316 excessive cAMP and mTOR signaling (de Joussineau et al., 2014; Sahut-Barnola et al., 2010). Whether

317 signaling activation in these tumor disposition syndromes is associated with altered phosphorylation of

318 GATA4 is unknown. Lending credence to this possibility, increased expression of GATA4 is evident in 319 the adrenal glands of Prkarla knockout mice signaling (Sahut-Barnola et al., 2010).

\subsection{GATA4 is expressed in canine testicular tumors}

A comprehensive survey of canine testicular tumors documented strong GATA4

323 immunoreactivity in all Sertoli cell tumors and the vast majority of (27/28) Leydig (interstitial) cell 324 tumors (Ramos-Vara and Miller, 2009). Mixed germ cell sex cord-stromal tumors (MGSCT) in this 325 species also expressed GATA4.

\subsection{Gata6 is downregulated in an experimental model of Leydig cell adenoma}

Heterozygous loss-of-function mutations in Menl, encoding a chromatin remodeling gene,

329 predispose mice to the development of multiple endocrine tumors, recapitulating the human MENI cancer

330 predisposition syndrome. Additionally, $M e n 1^{+/-}$mice develop gonadal somatic cell tumors, a feature not

331 typical of humans with this cancer predisposition syndrome. Female $\mathrm{MenI}^{+/-}$mice develop GCTs that

332 underexpress Gata6 (Table 3), while their male counterparts develop Leydig cell tumors that 
underexpress Gata6 (Mould et al., 2009). Loss of heterozygosity at the Men1 locus is evident in these gonadal tumors, suggesting a direct link between Menl gene inactivation and tumorigenesis in this model (Bertolino et al., 2003; Hussein et al., 2007). Decreased expression of Gata6 represents an attractive candidate for mediating gonadal somatic cells tumorigenesis in this model because: 1) GATA6 affects TGF $\beta$ signaling in other tumors such as colorectal neoplasms (see Section 1.4), 2) dysregulated TGF $\beta$ superfamily signaling accompanies Leydig cell tumorigenesis in the Men1 ${ }^{+/}$mice (Hussein et al., 2008), and 3) targeted mutagenesis of genes involved in TGF $\beta$ signaling (e.g., Inha, Amh, Amhr2) have been linked to testicular and ovarian somatic cell tumors in mice (Behringer et al., 1994; Matzuk et al., 1995; Mishina et al., 1996) (Table 3).

\subsection{Testicular adrenal rest tumors}

Leydig cells in the adult testis can arise from different populations of stem/progenitor cells, including undifferentiated mesenchymal cells in the testicular interstitium, vascular progenitors, and peritubular cells (Davidoff et al., 2004; Landreh et al., 2014; Mendis-Handagama and Ariyaratne, 2001). Men with disrupted adrenocortical function due to CYP21 or CYP11B1 deficiency develop neoplastic nodules of hormonally-active adrenocortical tissue in the testis (testicular adrenal rest tumors, TARTs), thought to arise from one of these reservoirs of pluripotential stem/progenitor cells (Reisch et al., 2013; Val et al., 2006). TARTs express adrenocortical-specific genes (CYP11B1, CYP11B2, and MC2R) at much higher levels than adjacent testicular tissue (Smeets et al., 2015). In addition, TARTs express the Leydig cell markers INSL3 and HSD17B3. These findings reinforce the premise that TARTs may arise from a totipotent embryonic cell type in response to hormonal dysregulation. The endocrine and paracrine factors that drive TART growth are not fully understood. A longitudinal analysis of men with CYP21 deficiency found no association between the presence of TARTs and parameters of disease control with exogenous glucocorticoids \pm mineralocorticoids (Reisch et al., 2013). Gata4/Gata6 double knockout mice generated with Sfl-cre develop TART-like cells that produce glucocorticoids (Padua et al., 2015). This 
GATA-deficient mouse model may be useful for exploring the signals that drive TART formation in humans (Heikinheimo et al., 2015).

\section{Adrenocortical neoplasms}

\subsection{GATA6 and GATA4 have been implicated in adrenocortical development and function}

GATA6 is the principal GATA factor expressed in the adrenal cortex. Gata6 is expressed diffusely in the adrenal cortex of the fetal mouse (Kiiveri et al., 2002). Postnatally, expression of Gata6 in the mouse adrenal is limited to capsular and subcapsular cells (Pihlajoki et al., 2013). In primates, GATA6 is expressed in the zona reticularis, where it is thought to regulate androgen biosynthesis (Jimenez et al., 2003; Nakamura et al., 2007; Nakamura et al., 2009). By comparison, GATA4 has a more restricted pattern of expression during adrenocortical development and is presumed to have a more limited role in the function of this organ (Kiiveri et al., 2002). During human development, GATA4 mRNA is evident in the fetal zone of the adrenal, but there is only weak expression of this transcript in the adrenal cortex postnatally. Similarly, Gata4 is transiently expressed in the mouse adrenal cortex during fetal but not postnatal development.

Consistent with its proposed role in the biosynthesis of adrenocorticoids and androgens, GATA6 has been shown to enhance the transcription of CYP11A1, CYP17A1, CYB5, SULT2A1, and HSD3B2 in cell lines [reviewed in (Röhrig et al., 2014)]. GATA4 can substitute for GATA6 in trans-activation studies of the CYP17A1 promoter (Flück and Miller, 2004), suggesting that GATA4 may serve to augment $C Y P 17 A 1$ expression during fetal development.

The impact of GATA6 on adrenocortical development and physiology has been assessed through conditional gene deletion using Sf1-cre (Pihlajoki et al., 2013). Gata6 conditional knockout mice exhibit a pleiotropic phenotype that includes: 1) a thin, cytomegalic adrenal cortex, 2) decreased expression of the zG differentiation marker Cyp1 1b2,3) blunted production of glucocorticoids in response to exogenous $\mathrm{ACTH}, 4)$ the spontaneous accumulation of non-steroidogenic cells expressing gonadal-like markers, 5) 
ectopic chromaffin cells, and 6) absence of an adrenal X-zone. Based on analogous conditional deletion studies of Gata6 in pulmonary (Tian et al., 2011; Zhang et al., 2008) and intestinal epithelia (Beuling et al., 2012; Beuling et al., 2011), GATA6 is hypothesized to regulate the balance between stem/progenitor cell expansion and differentiation in the adrenal cortex. Targeted ablation of Gata4 $_{\text {in }} \mathrm{SF} 1^{+}$cells has no significant impact on adrenocortical development, but Gata4/Gata6 double mutant mice exhibit adrenocortical aplasia (Padua et al., 2015).

\subsection{Gonadectomy-induced adrenocortical neoplasia}

Gonadectomy (GDX) triggers the appearance of gonadal-like neoplasms in the adrenal cortex of mice (Röhrig et al., 2014). This phenomenon, termed GDX-induced adrenocortical neoplasia, is thought to reflect the metaplastic differentiation of stem cells in the adrenal capsule/subcapsule in response to the hormonal changes that accompany GDX ( $\uparrow \mathrm{LH}, \downarrow$ inhibin, etc.). The neoplastic cells express Gata4, Lhcgr, Inha, and enzymes required for sex steroid biosynthesis (Cyp17al, Hsd17b3, Cyp19al) (Bielinska et al., 2006; Schillebeeckx et al., 2015). Prototypical adrenocortical markers, such as Gata6 and adrenocorticoid biosynthetic enzymes (Cyp21a1, Cyp11b1, Cyp11b2), are downregulated in the neoplastic adrenal tissue chimera studies suggest that strain susceptibility to GDX-induced neoplasia is cell-intrinsic and resides in 401 the stem/progenitor compartment (Röhrig et al., 2014). The genetic basis of strain susceptibility, however, 402 remains unclear. Linkage analysis of crosses between susceptible (DBA/2J) and non-susceptible $403(\mathrm{C} 57 \mathrm{Bl} / 6)$ mouse strains has shown that GDX-induced adrenocortical neoplasia is a complex trait 404 (Bernichtein et al., 2007). Loss- and gain-of-function studies have established that GATA4 directly modulates GDX406 induced adrenocortical neoplasia. Constitutive and conditional mutations in Gata4 mitigate the 407 accumulation of gonadal-like neoplastic cells and the expression of sex steroidogenic markers in the 408 adrenal cortex of gonadectomized female mice (Krachulec et al., 2012). Transgenic expression of Gata4 409 in the adrenal cortex using a Cyp21al promoter induces adrenocortical neoplasia in a non-susceptible 
strain (C57B1/6) (Chrusciel et al., 2013). Fate mapping studies suggest that GATA4 ${ }^{+}$neoplastic cells arise

411 from a distinctive pool of $\mathrm{WT}^{+}$progenitors in the adrenal capsule (Bandiera et al., 2013). Under basal

412 conditions, these cells give rise to normal steroidogenic cells in the adrenal cortex; GDX activates these

$413 \mathrm{WT} 1^{+}$progenitors and triggers their differentiation into gonadal-like steroidogenic tissue. Thus, $\mathrm{WT} 1^{+}$

414 capsular cells represent a reserve stem/progenitor cell population that can be mobilized in response to

415 extreme physiological demand (i.e., GDX-induced hormonal changes). These $\mathrm{WT}^{+}{ }^{+}$capsular cells are

416 presumed to be the progenitors of GDX-induced adrenocortical neoplasms. Whereas GATA4 drives

417 GDX-induced adrenocortical neoplasia, GATA6 appears to inhibit the process. Conditional deletion of

418 Gata6 using Sfl-cre augments the GDX-induced expression of gonadal-like markers in mice (Pihlajoki et 419 al., 2013).

GDX-induced adrenocortical neoplasia is a well documented phenomenon in not only mice but

421 also hamsters, ferrets, goats, and other domesticated species (Beuschlein et al., 2012; Bielinska et al.,

422 2009). Male Angora goats are routinely gonadectomized to enhance mohair production, and these castrate

423 animals have an increased incidence of adrenocortical adenomas (Altman et al., 1969). GDX-induced

424 adrenocortical neoplasia is a major cause of morbidity and mortality in pet ferrets, affecting up to $20 \%$ of

425 these animals. The neoplastic cells that accumulate in the adrenal glands of gonadectomized ferrets

426 express GATA4 (Fig 4) and other gonadal-like markers and secrete sex steroids (Bielinska et al., 2006;

427 Schillebeeckx et al., 2015).

428 There are related mouse models in which GDX triggers the accumulation of gonadal-like cells in

429 adrenal cortex. Following GDX, Inha-Tag mice develop malignant gonadal-like tumors, a process that is

430 thought to entail a feed-forward signaling loop involving Gata4 and Lhcgr (Rahman et al., 2004).

431 Similarly, Inha $a^{-/}$mice develop adrenocortical tumors in response to GDX (Matzuk et al., 1992). The

432 resultant tumors exhibit increased expression of Gata4 and other gonadal-like markers and a reciprocal

433 downregulation of Gata6 (Looyenga and Hammer, 2006). Enforced expression of LH enhances

434 adrenocortical neoplasia in Inha ${ }^{-/-}$mice (Beuschlein et al., 2003), whereas ablation of Smad3 attenuates

435 tumor growth in this model (Looyenga and Hammer, 2007). 

neoplasia even in the absence of GDX. Mice harboring multiple copies of the steroidogenic factor-1 (SfI) genetic

441 locus, mimicking the amplification of $S F 1$ seen in childhood adrenocortical carcinoma, develop

442 adrenocortical neoplasms that express gonadal-like markers including Gata4 (Doghman et al., 2007).

443 Activation of WNT/ $\beta$-catenin signaling is a hallmark of human adrenocortical tumors (Assie et al., 2014;

444 Tissier et al., 2005). Constitutive activation of $\beta$-catenin signaling, a hallmark of human adrenocortical 445 tumors, triggers the accumulation of GATA4 ${ }^{+}$cells in the subcapsule of mice (Berthon et al., 2010). 446 Similarly, overexpression of Igf2, a characteristic of human adrenocortical carcinomas, in the adrenal 447 cortex of mice leads to the accumulation of subcapsular cells that express Gata4 (Drelon et al., 2012). 448 Collectively, these results suggest that deregulation of GATA factors is probably a general feature of 449 adrenal tumorigenesis (at least in rodents), irrespective of whether it is triggered by GDX or genetic 450 alterations also found in patients.

\subsection{Expression of GATA4 and GATA6 in human adrenocortical tumors}

454 (Fig 5) and approximately one-third express GATA4 (Kiiveri et al., 2004). Diminished expression of 455 GATA6, SF1, and their target gene INHA in adrenocortical carcinomas correlates with poor outcome 456 (Parviainen et al., 2013). Overexpression of GATA6 in adrenocortical tumor cells enhances BMP 457 signaling, which inhibits cell proliferation and viability (Johnsen et al., 2009). Although global DNA 458 methylation surveys of human adrenocortical neoplasms have yielded inconsistent results, 459 hypermethylation and downregulation of both GATA6 and GATA4 have been reported (Fonseca et al., 460 2012; Rechache et al., 2012). 
462

463

\section{Parathyroid Neoplasms}

\subsection{Role of GATA3 in parathyroid development}

The parathyroid glands regulate calcium balance in the body through the secretion of parathyroid hormone (PTH). GATA3 expression has been reported in the second and third branchial arches, which harbor the progenitors of the parathyroid glands (Debacker et al., 1999; Grigorieva et al., 2010). The importance of GATA3 in parathyroid function has emerged from characterization of patients with hypoparathyroidism, sensorineural deafness, and renal anomaly (HDR) syndrome, a condition caused by heterozygous loss-of-function mutations in GATA3 (Ali et al., 2007; Nesbit et al., 2004; Van Esch et al., 2000). Using mouse models of HDR syndrome, investigators have shown that GATA3 is involved in the embryonic development of the parathyroid glands and in adult parathyroid cell proliferation (Grigorieva et al., 2010). Gata3 $^{--}$and $\mathrm{Gata}^{+--}$embryos have smaller parathyroid-thymus primordia, and the parathyroid glands of adult $\mathrm{Gata}^{+/-}$mice do not show increased proliferation or enlargement in response to hypocalcemia induced by a low calcium/vitamin D diet. These studies identified Gcm2, a gene required for proper parathyroid development, as a target of activation by GATA3.

\subsection{GATA3 is a marker of parathyroid neoplasms}

In two recent surveys of parathyroid tumors, GATA3 immunoreactivity was demonstrated in all parathyroid adenomas and carcinomas examined (Betts et al., 2014; Ordonez, 2014). As a tumor marker, GATA3 was found to be comparable in sensitivity and specificity to PTH, the marker that has traditionally been used in the diagnosis of parathyroid tumors.

\section{Pancreatic Neoplasms}

\subsection{Role of GATA4 and GATA6 in pancreatic development}


The pancreas is a mixed endocrine and exocrine gland that arises from the amalgamation of dorsal and ventral buds of foregut endoderm. A number of transcription factor genes, including $P d x l$ and Ptfla, have been shown to be essential for the early stages of pancreatic development in the mouse

490 (Oliver-Krasinski and Stoffers, 2008). GATA4 and GATA6 exhibit overlapping patterns of expression in 491 multipotential progenitor cells within the pancreatic anlagen (Decker et al., 2006; Ketola et al., 2004;

492 Ritz-Laser et al., 2005). As development proceeds, GATA4 expression predominates in pancreatic acinar 493 cells, while GATA6 predominates in the ductal compartment and a subpopulation of endocrine cells (Fig 494 6, 7) (Decker et al., 2006; Ketola et al., 2004).

GATA4 is able to transactivate the glucagon $(G c g)$ gene promoter in vitro (Ritz-Laser et al., 2005). The same study demonstrated that mutation of the GATA motif in the Gcg promoter reduces its basal promoter activity in glucagon producing cells. GATA6, but not GATA4, has been shown to physically interact with NKX2.2, an essential islet transcription factor (Decker et al., 2006). international consortium of investigators demonstrated that heterozygous mutations in human GATA6 501 cause a spectrum of pancreatic developmental defects ranging from agenesis to neonatal diabetes and 502 adult-onset diabetes (Bonnefond et al., 2012; De Franco et al., 2013; Lango Allen et al., 2012; Yorifuji et 503 al., 2012). Subsequently deletions or mutations of GATA4 were shown to be a monogenic cause of 504 neonatal and childhood-onset diabetes with variable exocrine phenotypes (Shaw-Smith et al., 2014). The 505 roles of GATA4 and GATA6 in pancreatic development and disease have been modeled in the mouse 506 (Carrasco et al., 2012; Decker et al., 2006; Martinelli et al., 2012; Watt et al., 2007; Xuan et al., 2012). 507 Expression of a GATA6-Engrailed dominant repressor fusion protein in pancreatic progenitors using a $508 P d x l$ promoter caused pancreatic hypoplasia (Decker et al., 2006). Analysis of embryos derived by 509 tetraploid complementation of Gata $^{-/-}$ES cells demonstrated a complete absence of the ventral but not 510 the dorsal pancreas; Gata6 $^{-1-}$ embryos displayed a similar, albeit less dramatic, phenotype (Watt et al., 511 2007). Conditional mutagenesis of either Gata4 or Gata6 in multipotent pancreatic progenitors (using $512 P d x l$-cre) has minimal impact on pancreatic development or function, whereas mutagenesis of both genes 
513 results in pancreatic agenesis and diabetes (Carrasco et al., 2012; Xuan et al., 2012). The double mutant

514 mice exhibit impaired proliferation of pancreatic progenitor cells, aberrant branching morphogenesis, and 515 a subsequent failure to induce the differentiation of progenitor cells expressing Cpal and Neurog3. The

516 prevailing hypothesis, based on the established roles of GATA4 and GATA6 in other foregut derivatives

517 such as the lung and intestine (Beuling et al., 2012; Zhang et al., 2008), is that GATA proteins, in

518 combination with other transcription factors, regulate the balance between stem cell expansion and

519 differentiation in the developing pancreas. Although GATA6 is preferentially expressed in endocrine

520 pancreas, conditional knockout mouse studies using Ptfla-cre have shown that GATA6 has direct effects

521 on survival of acinar cells in the exocrine pancreas (Martinelli et al., 2012). More recently, investigators

522 have generated $\beta$-cell specific knockouts of Gata4 or Gata6 and concluded that these factors have

523 important but nonessential roles in promoting endoplasmic reticulum integrity and $\beta$-cell survival, which

524 may contribute to the pathogenesis of type 1 diabetes (Sartori et al., 2014). The precise function of

525 GATA4 in mature pancreatic acinar cells is unclear.

526

6.2. GATA6 is downregulated in insulinomas triggered by MEN1 deficiency in the mouse

Mice harboring loss-of-function mutations in Menl develop multiple endocrine neoplasias (see

529 Section 3.4) including insulinomas (Serewko-Auret et al., 2010). Transcriptome analysis of isolated

530 control, normal, hyperplastic, and adenomous islets showed that Gata6 downregulation accompanies

531 tumor formation. It has been proposed that Gata6 dysregulation plays a fundamental role in tumor

532 formation and progression in this model by modulating TGF $\beta$ superfamily or WNT/ $\beta$-catenin signaling,

533 as in other systems (see Section 1.3).

\subsection{Roles of GATA6 and GATA4 in pancreatic ductal adenocarcinoma}

Although not an endocrine tumor, pancreatic ductal adenocarcinoma (PDA) sheds light on the

537 role of GATA factors in organogenesis and oncogenesis. PDA has a complex genomic landscape

538 characterized by frequent point mutations and copy number changes. Common genetic changes include 
activating mutations of $K R A S 2$ and inactivating mutations in the cell cycle regulator $C D K N 2 A$, the tumor suppressor TP53, and SMAD4 (Hong et al., 2011; Jones et al., 2008). GATA6 amplification and overexpression are hallmarks of PDA (Collisson et al., 2011; Fu et al., 2008; Kwei et al., 2008). Enforced expression of GATA6 in pancreatic cancer cell lines enhances proliferation and growth in soft agar, whereas inhibition of GATA6 impairs growth of pancreatic cancer cell lines. GATA6 activates signaling in pancreatic cancer by negatively regulating the WNT antagonist Dickkopf-1 (DKK1) (Zhong et al., 2011). Smoking is a major risk factor for pancreatic cancer, and a recent study showed that nicotine promotes progression of Kras-induced pancreatic adenocarcinoma via Gata6-dependent dedifferentiation of acinar cells (Hermann et al., 2014). GATA4 is frequently overexpressed and infrequently methylated in PDA, whereas GATA5 is generally hypermethylated in these neoplasms (Fu et al., 2007). A separate study documented GATA4 immunoreactivity in a majority of infiltrating pancreatic adenocarcinomas (Karafin et al., 2009).

\section{Pituitary neoplasms}

\subsection{Role of GATA2 in pituitary development and function}

Among differentiated hormone-secreting cell types found in the pituitary gland, both gonadotrope and thyrotrope cells express Gata2 from E10.5 onward in the mouse. The secretory products of thyrotrope and gonadotrope cells are heterodimers that share a common $\alpha$-glycoprotein subunit ( $\alpha \mathrm{GSU})$ and a specific $\beta$-subunit (FSH $\beta$, LH $\beta$, and thyrotropin- $\beta$ ) [reviewed in (Viger et al., 2008)]. The genes encoding $\alpha \mathrm{GSU}(C g a)$ and thyrotropin- $\beta(T s h b)$ are targets of activation by GATA2 (Gordon et al., 1997; Steger et al., 1994). This transcription factor has also been implicated in the regulation of the GnRH receptor gene (Schang et al., 2013).

Analyses of transgenic and knockout mice have established that GATA2 is involved in both gonadotrope and thyrotrope development (Charles et al., 2006; Dasen et al., 1999; Scully and Rosenfeld, 2002). Interactions between GATA2 and another transcription factor, PIT1, are critical determinants of 
565

566

567

568

569

570

571 572

pituitary cell fate (Dasen et al., 1999; Scully and Rosenfeld, 2002). In gonadotropes, where GATA2 is expressed in the absence of PIT1, GATA2 promotes the expression of gonadotrope-specific genes. In thyrotropes, where GATA2 and PIT1 are coexpressed, thyrotrope-specific genes are up-regulated by the binding of both factors to adjacent DNA cis-elements. PIT1 interacts via its homeodomain with a zinc finger of GATA2, modulating target gene transactivation (Dasen et al., 1999). Conditional ablation of Gata2 in the anterior pituitary reduces gonadotrope and thyrotrope cell numbers at birth and impairs the secretory capacity of these cells in the adult (Charles et al., 2006).

\subsection{GATA2 is a marker of pituitary neoplasms}

Consistent with its established role in gonadotrope and thyrotrope development GATA2 is found in most $\alpha$ GSU-positive and thyrotropin-secreting human pituitary adenomas (Umeoka et al., 2002; Wang et al., 2009).

\section{Summary and outlook}

Studies over the past two decades have established that GATA factors are required for the proper development, differentiation, and function of endocrine tissues. More recently, GATA factors have been implicated in forms of endocrine neoplasia (Table 5), although the molecular mechanisms involved are not fully understood. Altered GATA factor expression or function owing to acquired genetic (mutations, deletions, amplifications) or epigenetic changes (e.g., DNA methylation) has been linked to tumor formation. GATA factors can impact tumorigenesis through modulation of key developmental signaling pathways implicated in oncogenesis, such as the WNT/ $\beta$-catenin and TGF $\beta$ signaling pathways. In addition to affecting signaling pathways, GATA factor dysregulation can have effects on tumor cell metabolism, ploidy, and invasiveness.

Traditionally, transcription factors have been considered poorly druggable, but recent studies offer hope that GATA factors can be targeted pharmacologically in endocrine neoplasms. A small molecule inhibitor of GATA2 has been shown to suppress AR expression and exert anticancer activity 
against prostate cancer cell lines (He et al., 2014). It may be feasible to adopt similar approaches for inhibition of GATA factors in other tumors.

\section{Acknowledgments}

We apologize to investigators whose work was not directly cited due to space limitations. We thank Leila Unkila-Kallio and Jorma Toppari for a critical reading of the manuscript. We thank Ilkka Ketola and Sanne Kiiveri for providing photomicrographs, Matti Kiupel for providing ferret tumor specimens, and Rebecca Cochran for technical support. Grant support: NIH (DK52574, DK075618, and DA025744), AHA (13GRNT16850031), DOD grant PC141008, the Sigrid Jusélius Foundation, and the Academy of Finland.

\section{References}

Ali, A., Christie, P.T., Grigorieva, I.V., Harding, B., Van Esch, H., Ahmed, S.F., Bitner-Glindzicz, M., Blind, E., Bloch, C., Christin, P., et al. (2007). Functional characterization of GATA3 mutations causing the hypoparathyroidism-deafness-renal (HDR) dysplasia syndrome: insight into mechanisms of DNA binding by the GATA3 transcription factor. Hum Mol Genet 16, 265-275.

Allen, H.L., Flanagan, S.E., Shaw-Smith, C., De Franco, E., Akerman, I., Caswell, R., Ferrer, J., Hattersley, A.T., and Ellard, S. (2012). GATA6 haploinsufficiency causes pancreatic agenesis in humans. Nat Genet 44, 20-22.

Altman, N.H., Streett, C.S., and Terner, J.Y. (1969). Castration and its relationship to tumors of the adrenal gland in the goat. Am J Vet Res 30, 583-589.

Anttonen, M., Ketola, I., Parviainen, H., Pusa, A.K., and Heikinheimo, M. (2003). FOG-2 and GATA4 are coexpressed in the mouse ovary and can modulate Müllerian-inhibiting substance expression. Biol Reprod 68, 1333-1340.

Anttonen, M., Parviainen, H., Kyrönlahti, A., Bielinska, M., Wilson, D.B., Ritvos, O., and Heikinheimo, M. (2006). GATA-4 is a granulosa cell factor employed in inhibin-alpha activation by the TGF-beta pathway. J Mol Endocrinol 36, 557-568.

Anttonen, M., Pihlajoki, M., Andersson, N., Georges, A., L'Hote, D., Vattulainen, S., Farkkila, A., Unkila-Kallio, L., Veitia, R.A., and Heikinheimo, M. (2014). FOXL2, GATA4, and SMAD3 cooperatively modulate gene expression, cell viability and apoptosis in ovarian granulosa cell tumor cells. PLoS One 9, e85545.

Anttonen, M., Unkila-Kallio, L., Leminen, A., Butzow, R., and Heikinheimo, M. (2005). High GATA4 expression associates with aggressive behavior, whereas low anti-Mullerian hormone expression associates with growth potential of ovarian granulosa cell tumors. J Clin Endocrinol Metab 90, 65296535.

Aries, A., Paradis, P., Lefebvre, C., Schwartz, R.J., and Nemer, M. (2004). Essential role of GATA-4 in cell survival and drug-induced cardiotoxicity. Proc Natl Acad Sci U S A 101, 6975-6980. 
661

662

663

664

665

666

667

668

669

670

671

672

673

674

675

676

677

678

Assié, G., Letouze, E., Fassnacht, M., Jouinot, A., Luscap, W., Barreau, O., Omeiri, H., Rodriguez, S., Perlemoine, K., Rene-Corail, F., et al. (2014). Integrated genomic characterization of adrenocortical carcinoma. Nat Genet 46, 607-612.Ayanbule, F., Belaguli, N.S., and Berger, D.H. (2011). GATA factors in gastrointestinal malignancy. World journal of surgery 35, 1757-1765.

Bandiera, R., Vidal, V.P., Motamedi, F.J., Clarkson, M., Sahut-Barnola, I., von Gise, A., Pu, W.T., Hohenstein, P., Martinez, A., and Schedl, A. (2013). WT1 maintains Adrenal-Gonadal Primordium identity and marks a population of AGP-like progenitors within the adrenal gland. Dev Cell 27, 5-18.

Bashamboo, A., Brauner, R., Bignon-Topalovic, J., Lortat-Jacob, S., Karageorgou, V., Lourenco, D., Guffanti, A., and McElreavey, K. (2014). Mutations in the FOG2/ZFPM2 gene are associated with anomalies of human testis determination. Hum Mol Genet 23, 3657-3665.

Behringer, R.B., Finegold, M.J., and Cate, R.L. (1994). Mullerian-inhibiting substance function during mammalian sexual development. Cell 79, 415-425.

Bennett, J., Baumgarten, S.C., and Stocco, C. (2013). GATA4 and GATA6 silencing in ovarian granulosa cells affects levels of mRNAs involved in steroidogenesis, extracellular structure organization, IGF-I activity, and apoptosis. Endocrinology 154, 4845-4858.

Bennett, J., Wu, Y.G., Gossen, J., Zhou, P., and Stocco, C. (2012). Loss of GATA-6 and GATA-4 in granulosa cells blocks folliculogenesis, ovulation, and follicle stimulating hormone receptor expression leading to female infertility. Endocrinology 153, 2474-2485.

Bergeron, F., Nadeau, G., and R, S.V. (2015). GATA4 knockdown in MA-10 Leydig cells identifies multiple target genes in the steroidogenic pathway. Reproduction 149, 245-257.

Bernichtein, S., Petretto, E., Jamieson, S., Goel, A., Aitman, T.J., Mangion, J.M., and Huhtaniemi, I.T. (2007). Adrenal gland tumorigenesis after gonadectomy in mice is a complex genetic trait driven by epistatic loci. Endocrinology 149, 651-661.

Berthon, A., Sahut-Barnola, I., Lambert-Langlais, S., de Joussineau, C., Damon-Soubeyrand, C., Louiset, E., Taketo, M.M., Tissier, F., Bertherat, J., Lefrancois-Martinez, A.M., et al. (2010). Constitutive beta-catenin activation induces adrenal hyperplasia and promotes adrenal cancer development. Hum Mol Genet 19, 1561-1576.

Bertolino, P., Tong, W.M., Galendo, D., Wang, Z.Q., and Zhang, C.X. (2003). Heterozygous Men1 mutant mice develop a range of endocrine tumors mimicking multiple endocrine neoplasia type 1 . Mol Endocrinol 17, 1880-1892.

Betts, G., Beckett, E., and Nonaka, D. (2014). GATA3 shows differential immunohistochemical expression across thyroid and parathyroid lesions. Histopathology 65, 288-290.

Beuling, E., Aronson, B.E., Tran, L.M., Stapleton, K.A., Ter Horst, E.N., Vissers, L.A., Verzi, M.P., and Krasinski, S.D. (2012). GATA6 is required for proliferation, migration, secretory cell maturation, and gene expression in the mature mouse colon. Mol Cell Biol 32, 3392-3402.

Beuling, E., Baffour-Awuah, N.Y., Stapleton, K.A., Aronson, B.E., Noah, T.K., Shroyer, N.F., Duncan, S.A., Fleet, J.C., and Krasinski, S.D. (2011). GATA factors regulate proliferation, differentiation, and gene expression in small intestine of mature mice. Gastroenterology 140, 1219-1229 e1211-1212.

Beuschlein, F., Galac, S., and Wilson, D.B. (2012). Animal models of adrenocortical tumorigenesis. Mol Cell Endocrinol 351, 78-86.

Beuschlein, F., Looyenga, B.D., Bleasdale, S.E., Mutch, C., Bavers, D.L., Parlow, A.F., Nilson, J.H., and Hammer, G.D. (2003). Activin induces x-zone apoptosis that inhibits luteinizing hormone-dependent adrenocortical tumor formation in inhibin-deficient mice. Mol Cell Biol 23, 3951-3964.

Bielinska, M., Kiiveri, S., Parviainen, H., Mannisto, S., Heikinheimo, M., and Wilson, D.B. (2006). Gonadectomy-induced adrenocortical neoplasia in the domestic ferret (Mustela putorius furo) and laboratory mouse. Vet Pathol 43, 97-117.

Bielinska, M., Parviainen, H., Kiiveri, S., Heikinheimo, M., and Wilson, D.B. (2009). Review paper: origin and molecular pathology of adrenocortical neoplasms. Vet Pathol 46, 194-210.

Bielinska, M., Seehra, A., Toppari, J., Heikinheimo, M., and Wilson, D.B. (2007). GATA-4 is required for sex steroidogenic cell development in the fetal mouse. Dev Dyn 236, 203-213. 
679

680

681

682

683

684

685

686

687

688

689

690

691

692

693

694

695

696

697

698

699

700

701

702

703

704

705

706

707

708

709

710

711

712

713

714

715

716

717

718

719

720

721

722

723

724

725

726

727

728
Boerboom, D., Paquet, M., Hsieh, M., Liu, J., Jamin, S.P., Behringer, R.R., Sirois, J., Taketo, M.M., and Richards, J.S. (2005). Misregulated Wnt/beta-catenin signaling leads to ovarian granulosa cell tumor development. Cancer Res 65, 9206-9215.

Bonnefond, A., Sand, O., Guerin, B., Durand, E., De Graeve, F., Huyvaert, M., Rachdi, L., KerrConte, J., Pattou, F., Vaxillaire, M., et al. (2012). GATA6 inactivating mutations are associated with heart defects and, inconsistently, with pancreatic agenesis and diabetes. Diabetologia 55, 2845-2847.

Bouma, G.J., Washburn, L.L., Albrecht, K.H., and Eicher, E.M. (2007). Correct dosage of Fog2 and Gata4 transcription factors is critical for fetal testis development in mice. Proc Natl Acad Sci U S A 104, 14994-14999.

Bresnick, E.H., Katsumura, K.R., Lee, H.Y., Johnson, K.D., and Perkins, A.S. (2012). Master regulatory GATA transcription factors: mechanistic principles and emerging links to hematologic malignancies. Nucleic Acids Res 40, 5819-5831.

Bresnick, E.H., Lee, H.Y., Fujiwara, T., Johnson, K.D., and Keles, S. (2010). GATA switches as developmental drivers. J Biol Chem 285, 31087-31093.

Cai, K.Q., Caslini, C., Capo-chichi, C.D., Slater, C., Smith, E.R., Wu, H., Klein-Szanto, A.J., Godwin, A.K., and Xu, X.X. (2009). Loss of GATA4 and GATA6 expression specifies ovarian cancer histological subtypes and precedes neoplastic transformation of ovarian surface epithelia. PLoS One 4, e6454.

Capo-chichi, C.D., Cai, K.Q., Simpkins, F., Ganjei-Azar, P., Godwin, A.K., and Xu, X.X. (2011). Nuclear envelope structural defects cause chromosomal numerical instability and aneuploidy in ovarian cancer. BMC Med 9, 28.

Capo-chichi, C.D., Cai, K.Q., Testa, J.R., Godwin, A.K., and Xu, X.X. (2009). Loss of GATA6 leads to nuclear deformation and aneuploidy in ovarian cancer. Mol Cell Biol 29, 4766-4777.

Capo-chichi, C.D., Roland, I.H., Vanderveer, L., Bao, R., Yamagata, T., Hirai, H., Cohen, C., Hamilton, T.C., Godwin, A.K., and Xu, X.X. (2003). Anomalous expression of epithelial differentiationdetermining GATA factors in ovarian tumorigenesis. Cancer Res 63, 4967-4977.

Carrasco, M., Delgado, I., Soria, B., Martin, F., and Rojas, A. (2012). GATA4 and GATA6 control mouse pancreas organogenesis. J Clin Invest 122, 3504-3515.

Charles, M.A., Saunders, T.L., Wood, W.M., Owens, K., Parlow, A.F., Camper, S.A., Ridgway, E.C., and Gordon, D.F. (2006). Pituitary-specific Gata2 knockout: effects on gonadotrope and thyrotrope function. Mol Endocrinol 20, 1366-1377.

Chen, V.W., Ruiz, B., Killeen, J.L., Cote, T.R., Wu, X.C., and Correa, C.N. (2003). Pathology and classification of ovarian tumors. Cancer 97, 2631-2642.

Chiang, Y.T., Wang, K., Fazli, L., Qi, R.Z., Gleave, M.E., Collins, C.C., Gout, P.W., and Wang, Y. (2014). GATA2 as a potential metastasis-driving gene in prostate cancer. Oncotarget 5, 451-461.

Chou, J., Lin, J.H., Brenot, A., Kim, J.W., Provot, S., and Werb, Z. (2013). GATA3 suppresses metastasis and modulates the tumour microenvironment by regulating microRNA-29b expression. Nat Cell Biol 15, 201-213.

Chou, J., Provot, S., and Werb, Z. (2010). GATA3 in development and cancer differentiation: cells GATA have it! J Cell Physiol 222, 42-49.

Chrusciel, M., Vuorenoja, S., Mohanty, B., Rivero-Muller, A., Li, X., Toppari, J., Huhtaniemi, I., and Rahman, N.A. (2013). Transgenic GATA-4 expression induces adrenocortical tumorigenesis in C57Bl/6 mice. J Cell Sci 126, 1845-1857.

Collisson, E.A., Sadanandam, A., Olson, P., Gibb, W.J., Truitt, M., Gu, S., Cooc, J., Weinkle, J., Kim, G.E., Jakkula, L., et al. (2011). Subtypes of pancreatic ductal adenocarcinoma and their differing responses to therapy. Nat Med 17, 500-503.

Crispino, J.D., and Weiss, M.J. (2014). Erythro-megakaryocytic transcription factors associated with hereditary anemia. Blood 123, 3080-3088.

Dasen, J.S., O'Connell, S.M., Flynn, S.E., Treier, M., Gleiberman, A.S., Szeto, D.P., Hooshmand, F., Aggarwal, A.K., and Rosenfeld, M.G. (1999). Reciprocal interactions of Pit1 and GATA2 mediate signaling gradient-induced determination of pituitary cell types. Cell 97, 587-598. 
764

765

766

767

768

769

770

771

772

773

774

775

776

777

778

Davidoff, M.S., Middendorff, R., Enikolopov, G., Riethmacher, D., Holstein, A.F., and Muller, D. (2004). Progenitor cells of the testosterone-producing Leydig cells revealed. J Cell Biol 167, 935-944.

De Franco, E., Shaw-Smith, C., Flanagan, S.E., Shepherd, M.H., Hattersley, A.T., and Ellard, S. (2013). GATA6 mutations cause a broad phenotypic spectrum of diabetes from pancreatic agenesis to adult-onset diabetes without exocrine insufficiency. Diabetes 62, 993-997.

de Joussineau, C., Sahut-Barnola, I., Tissier, F., Dumontet, T., Drelon, C., Batisse-Lignier, M., Tauveron, I., Pointud, J.C., Lefrancois-Martinez, A.M., Stratakis, C.A., et al. (2014). mTOR pathway is activated by PKA in adrenocortical cells and participates in vivo to apoptosis resistance in primary pigmented nodular adrenocortical disease (PPNAD). Hum Mol Genet.

Debacker, C., Catala, M., and Labastie, M.C. (1999). Embryonic expression of the human GATA-3 gene. Mech Dev 85, 183-187.

Decker, K., Goldman, D.C., Grasch, C.L., and Sussel, L. (2006). Gata6 is an important regulator of mouse pancreas development. Dev Biol 298, 415-429.

Doghman, M., Karpova, T., Rodrigues, G.A., Arhatte, M., De, M.J., Cavalli, L.R., Virolle, V., Barbry, P., Zambetti, G.P., Figueiredo, B.C., et al. (2007). Increased steroidogenic factor-1 dosage triggers adrenocortical cell proliferation and cancer. Mol Endocrinol 21, 2968-2987.

Drelon, C., Berthon, A., Ragazzon, B., Tissier, F., Bandiera, R., Sahut-Barnola, I., de Joussineau, C., Batisse-Lignier, M., Lefrancois-Martinez, A.M., Bertherat, J., et al. (2012). Analysis of the role of Igf2 in adrenal tumour development in transgenic mouse models. PLoS One 7, e44171.

Dyson, M.T., Roqueiro, D., Monsivais, D., Ercan, C.M., Pavone, M.E., Brooks, D.C., Kakinuma, T., Ono, M., Jafari, N., Dai, Y., et al. (2014). Genome-wide DNA methylation analysis predicts an epigenetic switch for GATA factor expression in endometriosis. PLoS Genet 10, e1004158.

Efimenko, E., Padua, M.B., Manuylov, N.L., Fox, S.C., Morse, D.A., and Tevosian, S.G. (2013). The transcription factor GATA4 is required for follicular development and normal ovarian function. Dev Biol 381, 144-158.

Färkkilä, A., Andersson, N., Butzow, R., Leminen, A., Heikinheimo, M., Anttonen, M., and UnkilaKallio, L. (2014). HER2 and GATA4 are new prognostic factors for early-stage ovarian granulosa cell tumor-a long-term follow-up study. Cancer Med 3, 526-536.

Flück, C.E., and Miller, W.L. (2004). GATA-4 and GATA-6 modulate tissue-specific transcription of the human gene for P450c17 by direct interaction with Sp1. Mol Endocrinol 18, 1144-1157.

Fonseca, A.L., Kugelberg, J., Starker, L.F., Scholl, U., Choi, M., Hellman, P., Akerstrom, G., Westin, G., Lifton, R.P., Bjorklund, P., et al. (2012). Comprehensive DNA methylation analysis of benign and malignant adrenocortical tumors. Genes Chromosomes Cancer 51, 949-960.

Fu, B., Guo, M., Wang, S., Campagna, D., Luo, M., Herman, J.G., and Iacobuzio-Donahue, C.A. (2007). Evaluation of GATA-4 and GATA-5 methylation profiles in human pancreatic cancers indicate promoter methylation patterns distinct from other human tumor types. Cancer Biol Ther 6, 1546-1552.

$\mathrm{Fu}$, B., Luo, M., Lakkur, S., Lucito, R., and Iacobuzio-Donahue, C.A. (2008). Frequent genomic copy number gain and overexpression of GATA-6 in pancreatic carcinoma. Cancer Biol Ther 7, 1593-1601.

Fuller, P.J., Chu, S., Fikret, S., and Burger, H.G. (2002). Molecular pathogenesis of granulosa cell tumours. Mol Cell Endocrinol 191, 89-96.

Gautier, E.L., Ivanov, S., Williams, J.W., Huang, S.C., Marcelin, G., Fairfax, K., Wang, P.L., Francis, J.S., Leone, P., Wilson, D.B., et al. (2014). Gata6 regulates aspartoacylase expression in resident peritoneal macrophages and controls their survival. J Exp Med 211, 1525-1531.

Gordon, D.F., Lewis, S.R., Haugen, B.R., James, R.A., McDermott, M.T., Wood, W.M., and Ridgway, E.C. (1997). Pit-1 and GATA-2 interact and functionally cooperate to activate the thyrotropin betasubunit promoter. J Biol Chem 272, 24339-24347.

Gourgari, E., Saloustros, E., and Stratakis, C.A. (2012). Large-cell calcifying Sertoli cell tumors of the testes in pediatrics. Curr Opin Pediatr 24, 518-522.

Grigorieva, I.V., Mirczuk, S., Gaynor, K.U., Nesbit, M.A., Grigorieva, E.F., Wei, Q., Ali, A., Fairclough, R.J., Stacey, J.M., Stechman, M.J., et al. (2010). Gata3-deficient mice develop parathyroid 
814

815

816

817

818

819

820

821

822

823

824

825

826

827

828

abnormalities due to dysregulation of the parathyroid-specific transcription factor Gcm2. J Clin Invest $120,2144-2155$.

He, B., Lanz, R.B., Fiskus, W., Geng, C., Yi, P., Hartig, S.M., Rajapakshe, K., Shou, J., Wei, L., Shah, S.S., et al. (2014). GATA2 facilitates steroid receptor coactivator recruitment to the androgen receptor complex. Proc Natl Acad Sci U S A 111, 18261-18266.

Heikinheimo, M., Ermolaeva, M., Bielinska, M., Rahman, N.A., Narita, N., Huhtaniemi, I.T., Tapanainen, J.S., and Wilson, D.B. (1997). Expression and hormonal regulation of transcription factors GATA-4 and GATA-6 in the mouse ovary. Endocrinology 138, 3505-3514.

Heikinheimo, M., Pihlajoki, M., Schrade, A., Kyronlahti, A., and Wilson, D.B. (2015). Testicular steroidogenic cells to the rescue. Endocrinology 156, 1616-1619.

Hermann, P.C., Sancho, P., Canamero, M., Martinelli, P., Madriles, F., Michl, P., Gress, T., de Pascual, R., Gandia, L., Guerra, C., et al. (2014). Nicotine promotes initiation and progression of KRASinduced pancreatic cancer via Gata6-dependent dedifferentiation of acinar cells in mice. Gastroenterology 147, 1119-1133 e1114.

Hong, S.M., Park, J.Y., Hruban, R.H., and Goggins, M. (2011). Molecular signatures of pancreatic cancer. Arch Pathol Lab Med 135, 716-727.

Hu, Y.C., Nicholls, P.K., Soh, Y.Q., Daniele, J.R., Junker, J.P., van Oudenaarden, A., and Page, D.C. (2015). Licensing of primordial germ cells for gametogenesis depends on genital ridge signaling. PLoS Genet 11 , e1005019.

$\mathrm{Hu}$, Y.C., Okumura, L.M., and Page, D.C. (2013). Gata4 is required for formation of the genital ridge in mice. PLoS Genet 9, e1003629.

Huang, C.C., and Yao, H.H. (2010). Inactivation of Dicer1 in Steroidogenic factor 1-positive cells reveals tissue-specific requirement for Dicer1 in adrenal, testis, and ovary. BMC Dev Biol 10, 66.

Hussein, N., Casse, H., Fontaniere, S., Morera, A.M., Asensio, M.J., Bakeli, S., Lu, J.L., Coste, I., Di Clemente, N., Bertolino, P., et al. (2007). Reconstituted expression of menin in Men1-deficient mouse Leydig tumour cells induces cell cycle arrest and apoptosis. Eur J Cancer 43, 402-414.

Hussein, N., Lu, J., Casse, H., Fontaniere, S., Morera, A.M., Guittot, S.M., Calender, A., Di Clemente, N., and Zhang, C.X. (2008). Deregulation of anti-Mullerian hormone/BMP and transforming growth factor-beta pathways in Leydig cell lesions developed in male heterozygous multiple endocrine neoplasia type 1 mutant mice. Endocr Relat Cancer 15, 217-227.

Imai, T., Kawai, Y., Tadokoro, Y., Yamamoto, M., Nishimune, Y., and Yomogida, K. (2004). In vivo and in vitro constant expression of GATA-4 in mouse postnatal Sertoli cells. Mol Cell Endocrinol 214, 107-115.

Jamieson, S., Butzow, R., Andersson, N., Alexiadis, M., Unkila-Kallio, L., Heikinheimo, M., Fuller, P.J., and Anttonen, M. (2010). The FOXL2 C134W mutation is characteristic of adult granulosa cell tumors of the ovary. Mod Pathol 23, 1477-1485.

Jamieson, S., and Fuller, P.J. (2012). Molecular pathogenesis of granulosa cell tumors of the ovary. Endocrine reviews 33, 109-144.

Jimenez, P., Saner, K., Mayhew, B., and Rainey, W.E. (2003). GATA-6 is expressed in the human adrenal and regulates transcription of genes required for adrenal androgen biosynthesis. Endocrinology $144,4285-4288$.

Johnsen, I.K., Kappler, R., Auernhammer, C.J., and Beuschlein, F. (2009). Bone morphogenetic proteins 2 and 5 are down-regulated in adrenocortical carcinoma and modulate adrenal cell proliferation and steroidogenesis. Cancer Res 69, 5784-5792.

Jones, S., Zhang, X., Parsons, D.W., Lin, J.C., Leary, R.J., Angenendt, P., Mankoo, P., Carter, H., Kamiyama, H., Jimeno, A., et al. (2008). Core signaling pathways in human pancreatic cancers revealed by global genomic analyses. Science 321, 1801-1806.

Kalfa, N., Philibert, P., Patte, C., Ecochard, A., Duvillard, P., Baldet, P., Jaubert, F., Fellous, M., and Sultan, C. (2007). Extinction of FOXL2 expression in aggressive ovarian granulosa cell tumors in children. Fertil Steril 87, 896-901. 
866

867

868

869

870

871

872

873

874

875

876

877
Kananen, K., Markkula, M., Rainio, E., Su, J.G., Hsueh, A.J., and Huhtaniemi, I.T. (1995). Gonadal tumorigenesis in transgenic mice bearing the mouse inhibin alpha-subunit promoter/simian virus Tantigen fusion gene: characterization of ovarian tumors and establishment of gonadotropin-responsive granulosa cell lines. Mol Endocrinol 9, 616-627.

Karafin, M.S., Cummings, C.T., Fu, B., and Iacobuzio-Donahue, C.A. (2009). The developmental transcription factor Gata4 is overexpressed in pancreatic ductal adenocarcinoma. Int J Clin Exp Pathol 3, 47-55.

Ketola, I., Anttonen, M., Vaskivuo, T., Tapanainen, J.S., Toppari, J., and Heikinheimo, M. (2002). Developmental expression and spermatogenic stage specificity of transcription factors GATA-1 and GATA-4 and their cofactors FOG-1 and FOG-2 in the mouse testis. Eur J Endocrinol 147, 397-406.

Ketola, I., Otonkoski, T., Pulkkinen, M.A., Niemi, H., Palgi, J., Jacobsen, C.M., Wilson, D.B., and Heikinheimo, M. (2004). Transcription factor GATA-6 is expressed in the endocrine and GATA-4 in the exocrine pancreas. Mol Cell Endocrinol 226, 51-57.

Ketola, I., Pentikainen, V., Vaskivuo, T., Ilvesmaki, V., Herva, R., Dunkel, L., Tapanainen, J.S., Toppari, J., and Heikinheimo, M. (2000). Expression of transcription factor GATA-4 during human testicular development and disease. J Clin Endocrinol Metab 85, 3925-3931.

Ketola, I., Rahman, N., Toppari, J., Bielinska, M., Porter-Tinge, S.B., Tapanainen, J.S., Huhtaniemi, I.T., Wilson, D.B., and Heikinheimo, M. (1999). Expression and regulation of transcription factors GATA-4 and GATA-6 in developing mouse testis. Endocrinology 140, 1470-1480.

Ketola, I., Toppari, J., Vaskivuo, T., Herva, R., Tapanainen, J.S., and Heikinheimo, M. (2003). Transcription factor GATA-6, cell proliferation, apoptosis, and apoptosis-related proteins Bcl-2 and Bax in human fetal testis. J Clin Endocrinol Metab 88, 1858-1865.

Kiiveri, S., Liu, J., Heikkila, P., Arola, J., Lehtonen, E., Voutilainen, R., and Heikinheimo, M. (2004). Transcription factors GATA-4 and GATA-6 in human adrenocortical tumors. Endocr Res 30, 919-923.

Kiiveri, S., Liu, J., Westerholm-Ormio, M., Narita, N., Wilson, D.B., Voutilainen, R., and Heikinheimo, M. (2002). Differential expression of GATA-4 and GATA-6 in fetal and adult mouse and human adrenal tissue. Endocrinology 143, 3136-3143.

Kilcoyne, K.R., Smith, L.B., Atanassova, N., Macpherson, S., McKinnell, C., van den Driesche, S., Jobling, M.S., Chambers, T.J., De Gendt, K., Verhoeven, G., et al. (2014). Fetal programming of adult Leydig cell function by androgenic effects on stem/progenitor cells. Proc Natl Acad Sci U.S.A. 111, E1924-1932.

Kim, G.J., Georg, I., Scherthan, H., Merkenschlager, M., Guillou, F., Scherer, G., and Barrionuevo, F. (2010a). Dicer is required for Sertoli cell function and survival. Int J Dev Biol 54, 867-875.

Kim, M.S., Hur, S.Y., Yoo, N.J., and Lee, S.H. (2010b). Mutational analysis of FOXL2 codon 134 in granulosa cell tumour of ovary and other human cancers. J \{athol 221, 147-152.

Kobayashi, S., Volden, P., Timm, D., Mao, K., Xu, X., and Liang, Q. (2010). Transcription factor GATA4 inhibits doxorubicin-induced autophagy and cardiomyocyte death. J Biol Chem 285, 793-804.

Krachulec, J., Vetter, M., Schrade, A., Löbs, A.K., Bielinska, M., Cochran, R., Kyrönlahti, A., Pihlajoki, M., Parviainen, H., Jay, P.Y., et al. (2012). GATA4 is a critical regulator of gonadectomyinduced adrenocortical tumorigenesis in mice. Endocrinology 153, 2599-2611.

Kwei, K.A., Bashyam, M.D., Kao, J., Ratheesh, R., Reddy, E.C., Kim, Y.H., Montgomery, K., Giacomini, C.P., Choi, Y.L., Chatterjee, S., et al. (2008). Genomic profiling identifies GATA6 as a candidate oncogene amplified in pancreatobiliary cancer. PLoS Genet 4, e1000081.

Kyrönlahti, A., Euler, R., Bielinska, M., Schoeller, E.L., Moley, K.H., Toppari, J., Heikinheimo, M., and Wilson, D.B. (2011a). GATA4 regulates Sertoli cell function and fertility in adult male mice. Mol Cell Endocrinol 333, 85-95.

Kyrönlahti, A., Kauppinen, M., Lind, E., Unkila-Kallio, L., Butzow, R., Klefstrom, J., Wilson, D.B., Anttonen, M., and Heikinheimo, M. (2010). GATA4 protects granulosa cell tumors from TRAIL-induced apoptosis. Endocr Relat Cancer 17, 709-717. 
878

879

880

881

882

883

884

885

886

887

888

889

890

891

892

893

894

895

896

897

898

899

900

901

902

903

904

905

906

907

908

909

910

911

912

913

914

915

916

917

918

919

920

921

922

923

924

925

926

927

928
Kyrönlahti, A., Ramo, M., Tamminen, M., Unkila-Kallio, L., Butzow, R., Leminen, A., Nemer, M., Rahman, N., Huhtaniemi, I., Heikinheimo, M., et al. (2008). GATA-4 regulates Bcl-2 expression in ovarian granulosa cell tumors. Endocrinology 149, 5635-5642.

Kyrönlahti, A., Vetter, M., Euler, R., Bielinska, M., Jay, P.Y., Anttonen, M., Heikinheimo, M., and Wilson, D.B. (2011b). GATA4 deficiency impairs ovarian function in adult mice. Biol Reprod 84, 10331044.

L'Hote, D., Georges, A., Todeschini, A.L., Kim, J.H., Benayoun, B.A., Bae, J., and Veitia, R.A. (2012). Discovery of novel protein partners of the transcription factor FOXL2 provides insights into its physiopathological roles. Hum Mol Genet 21, 3264-3274.

Laitinen, M.P., Anttonen, M., Ketola, I., Wilson, D.B., Ritvos, O., Butzow, R., and Heikinheimo, M. (2000). Transcription factors GATA-4 and GATA-6 and a GATA family cofactor, FOG-2, are expressed in human ovary and sex cord-derived ovarian tumors. J Clin Endocrinol Metab 85, 3476-3483.

Landreh, L., Spinnler, K., Schubert, K., Hakkinen, M.R., Auriola, S., Poutanen, M., Soder, O., Svechnikov, K., and Mayerhofer, A. (2014). Human testicular peritubular cells host putative stem leydig cells with steroidogenic capacity. J Clin Endocrinol Metab 99, E1227-1235.

Lango Allen, H., Flanagan, S.E., Shaw-Smith, C., De Franco, E., Akerman, I., Caswell, R., Ferrer, J., Hattersley, A.T., and Ellard, S. (2012). GATA6 haploinsufficiency causes pancreatic agenesis in humans. Nat Genet 44, 20-22.

LaVoie, H.A. (2003). The role of GATA in mammalian reproduction. Exp Biol Med 228, 1282-1290.

LaVoie, H.A. (2014). The GATA-keepers of ovarian development and folliculogenesis. Biol Reprod $91,38$.

LaVoie, H.A., McCoy, G.L., and Blake, C.A. (2004). Expression of the GATA-4 and GATA-6 transcription factors in the fetal rat gonad and in the ovary during postnatal development and pregnancy. Mol Cell Endocrinol 227, 31-40.

Lei, L., Jin, S., Gonzalez, G., Behringer, R.R., and Woodruff, T.K. (2010). The regulatory role of Dicer in folliculogenesis in mice. Mol Cell Endocrinol 315, 63-73.

Lindeboom, F., Gillemans, N., Karis, A., Jaegle, M., Meijer, D., Grosveld, F., and Philipsen, S. (2003). A tissue-specific knockout reveals that Gata1 is not essential for Sertoli cell function in the mouse. Nucleic Acids Res 31, 5405-5412.

Looyenga, B.D., and Hammer, G.D. (2006). Origin and identity of adrenocortical tumors in inhibin knockout mice: implications for cellular plasticity in the adrenal cortex. Mol Endocrinol 20, 2848-2863.

Looyenga, B.D., and Hammer, G.D. (2007). Genetic removal of Smad3 from inhibin-null mice attenuates tumor progression by uncoupling extracellular mitogenic signals from the cell cycle machinery. Mol Endocrinol 21, 18.

Lourenco, D., Brauner, R., Rybczynska, M., Nihoul-Fekete, C., McElreavey, K., and Bashamboo, A. (2011). Loss-of-function mutation in GATA4 causes anomalies of human testicular development. Proceedings of the National Academy of Sciences of the United States of America 108, 1597-1602.

Maitra, M., Koenig, S.N., Srivastava, D., and Garg, V. (2010). Identification of GATA6 sequence variants in patients with congenital heart defects. Pediatr Res 68, 281-285.

Manuylov, N.L., Fujiwara, Y., Adameyko, I.I., Poulat, F., and Tevosian, S.G. (2007). The regulation of Sox9 gene expression by the GATA4/FOG2 transcriptional complex in dominant XX sex reversal mouse models. Dev Biol 307, 356-367.

Manuylov, N.L., Zhou, B., Ma, Q., Fox, S.C., Pu, W.T., and Tevosian, S.G. (2011). Conditional ablation of Gata4 and Fog2 genes in mice reveals their distinct roles in mammalian sexual differentiation. Dev Biol 353, 229-241.

Martinelli, P., Canamero, M., Del Pozo, N., Madriles, F., Zapata, A., and Real, F.X. (2012). Gata6 is required for complete acinar differentiation and maintenance of the exocrine pancreas in adult mice. Gut.

Matzuk, M.M., Finegold, M.J., Su, J.G., Hsueh, A.J., and Bradley, A. (1992). Alpha-inhibin is a tumour-suppressor gene with gonadal specificity in mice. Nature 360, 313-319.

Matzuk, M.M., Kumar, T.R., and Bradley, A. (1995). Different phenotypes for mice deficient in either activins or activin receptor type II. Nature 374, 356-600. 
961

962

963

964

965

966

967

968

969

970

971

972

973

974

975

976

977

978

979

Mazaud-Guittot, S., Prud'homme, B., Bouchard, M.F., Bergeron, F., Daems, C., Tevosian, S.G., and Viger, R.S. (2014). GATA4 Autoregulates Its Own Expression in Mouse Gonadal Cells via Its Distal 1b Promoter. Biol Reprod 90, 25.

McCoard, S.A., Wise, T.H., Fahrenkrug, S.C., and Ford, J.J. (2001). Temporal and spatial localization patterns of Gata4 during porcine gonadogenesis. Biol Reprod 65, 366-374.

Mendis-Handagama, S.M., and Ariyaratne, H.B. (2001). Differentiation of the adult Leydig cell population in the postnatal testis. Biol Reprod 65, 660-671.

Middlebrook, B.S., Eldin, K., Li, X., Shivasankaran, S., and Pangas, S.A. (2009). Smad1-Smad5 ovarian conditional knockout mice develop a disease profile similar to the juvenile form of human granulosa cell tumors. Endocrinology 150, 5208-5217.

Mishina, Y., Rey, R., Finegold, M.J., Matzuk, M.M., Josso, N., Cate, R.L., and Behringer, R.R. (1996). Genetic analysis of the Müllerian-inhibiting substance signal transduction pathway in mammalian sexual differentiation. Genes Dev 10, 2577-2587.

Miyamoto, Y., Taniguchi, H., Hamel, F., Silversides, D.W., and Viger, R.S. (2008). A GATA4/WT1 cooperation regulates transcription of genes required for mammalian sex determination and differentiation. BMC Mol Biol 9, 44.

Molkentin, J.D. (2000). The zinc finger-containing transcription factors GATA-4, -5, and -6: Ubiquitously expressed regulators of tissue-specific gene expression. Journal of Biological Chemistry 275, 38949-38952.

Morse, C.B., McLaren, J.F., Roy, D., Siegelman, E.S., Livolsi, V.A., and Gracia, C.R. (2011). Ovarian preservation in a young patient with Gorlin syndrome and multiple bilateral ovarian masses. Fertil Steril 96, e47-50.

Mosbech, C.H., Svingen, T., Nielsen, J.E., Toft, B.G., Rechnitzer, C., Petersen, B.L., Rajpert-De Meyts, E., and Hoei-Hansen, C.E. (2014). Expression pattern of clinically relevant markers in paediatric germ cell- and sex-cord stromal tumours is similar to adult testicular tumours. Virchows Arch 465, 567577.

Mould, A.W., Duncan, R., Serewko-Auret, M., Loffler, K.A., Biondi, C., Gartside, M., Kay, G.F., and Hayward, N.K. (2009). Global expression profiling of sex cord stromal tumors from Men1 heterozygous mice identifies altered TGF-beta signaling, decreased Gata6 and increased Csf1r expression. Int J Cancer $124,1122-1132$.

Nagaraja, A.K., Andreu-Vieyra, C., Franco, H.L., Ma, L., Chen, R., Han, D.Y., Zhu, H., Agno, J.E., Gunaratne, P.H., DeMayo, F.J., et al. (2008). Deletion of Dicer in somatic cells of the female reproductive tract causes sterility. Mol Endocrinol 22, 2336-2352.

Nakamura, Y., Suzuki, T., and Sasano, H. (2007). Transcription factor GATA-6 in the human adrenocortex: association with adrenal development and aging. Endocr J 54, 783-789.

Nakamura, Y., Xing, Y., Sasano, H., and Rainey, W.E. (2009). The mediator complex subunit 1 enhances transcription of genes needed for adrenal androgen production. Endocrinology 150, 4145-4153.

Nesbit, M.A., Bowl, M.R., Harding, B., Ali, A., Ayala, A., Crowe, C., Dobbie, A., Hampson, G., Holdaway, I., Levine, M.A., et al. (2004). Characterization of GATA3 mutations in the hypoparathyroidism, deafness, and renal dysplasia (HDR) syndrome. J Biol Chem 279, 22624-22634.

Nezhat, F.R., Apostol, R., Nezhat, C., and Pejovic, T. (2015). New insights in the pathophysiology of ovarian cancer and implications for screening and prevention. Am J Obstet Gynecol.

Nouriani, M., Felix, J.C., and Dubeau, L. (2002). Histogenesis and histopathological characterisrics of Sertoli-Leydig cell tumors. CME Journal of Gynecologic Oncology 7, 114-120.

Oliver-Krasinski, J.M., and Stoffers, D.A. (2008). On the origin of the beta cell. Genes Dev 22, 19982021.

Ordonez, N.G. (2014). Value of GATA3 Immunostaining in the Diagnosis of Parathyroid Tumors. Appl Immunohistochem Mol Morphol 22, 756-761.

Oreal, E., Mazaud, S., Picard, J.Y., Magre, S., and Carre-Eusebe, D. (2002). Different patterns of antiMullerian hormone expression, as related to DMRT1, SF-1, WT1, GATA-4, Wnt-4, and Lhx9 expression, in the chick differentiating gonads. Dev Dyn 225, 221-232. 
1011

1012

1013

1014

1015

1016

1017

1018

1019

1020

1021

1022

1023

1024

1025

1026

1027

1028
Padua, M.B., Fox, S.C., Jiang, T., Morse, D.A., and Tevosian, S.G. (2014). Simultaneous gene deletion of gata4 and gata6 leads to early disruption of follicular development and germ cell loss in the murine ovary. Biol Reprod 91, 24.

Padua, M.B., Jiang, T., Morse, D.A., Fox, S.C., Hatch, H.M., and Tevosian, S.G. (2015). Combined loss of the GATA4 and GATA6 transcription factors in male mice disrupts testicular development and confers adrenal-like function in the testes. Endocrinology 156, 1873-86.

Pangas, S.A., Li, X., Umans, L., Zwijsen, A., Huylebroeck, D., Gutierrez, C., Wang, D., Martin, J.F., Jamin, S.P., Behringer, R.R., et al. (2008). Conditional deletion of Smad1 and Smad5 in somatic cells of male and female gonads leads to metastatic tumor development in mice. Mol Cell Biol 28, 248-257.

Parviainen, H., Schrade, A., Kiiveri, S., Prunskaite-Hyyrylainen, R., Haglund, C., Vainio, S., Wilson, D.B., Arola, J., and Heikinheimo, M. (2013). Expression of Wnt and TGF-beta pathway components and key adrenal transcription factors in adrenocortical tumors: association to carcinoma aggressiveness. Pathol Res Pract 209, 503-509.

Patient, R.K., and McGhee, J.D. (2002). The GATA family (vertebrates and invertebrates). Curr Opin Genet Dev 12, 416-422.

Pihlajoki, M., Gretzinger, E., Cochran, R., Kyrönlahti, A., Schrade, A., Hiller, T., Sullivan, L., Shoykhet, M., Schoeller, E.L., Brooks, M.D., et al. (2013). Conditional mutagenesis of Gata6 in SF1positive cells causes gonadal-like differentiation in the adrenal cortex of mice. Endocrinology 154, 17541767.

Prendiville, T., Jay, P.Y., and Pu, W.T. (2014). Insights into the genetic structure of congenital heart disease from human and murine studies on monogenic disorders. Cold Spring Harb Perspect Med 4, Oct 1, doi: 10.1101/cshperspect.a013946.

Rahman, N.A., Kiiveri, S., Rivero-Muller, A., Levallet, J., Vierre, S., Kero, J., Wilson, D.B., Heikinheimo, M., and Huhtaniemi, I. (2004). Adrenocortical tumorigenesis in transgenic mice expressing the inhibin alpha-subunit promoter/SV40 virus T-antigen transgene: Relationship between ectopic expression of luteinizing hormone receptor and transcription factor GATA-4. Mol Endocrinol 18, 25532569.

Ramos-Vara, J.A., and Miller, M.A. (2009). Immunohistochemical evaluation of GATA-4 in canine testicular tumors. Vet Pathol 46, 893-896.

Rechache, N.S., Wang, Y., Stevenson, H.S., Killian, J.K., Edelman, D.C., Merino, M., Zhang, L., Nilubol, N., Stratakis, C.A., Meltzer, P.S., et al. (2012). DNA methylation profiling identifies global methylation differences and markers of adrenocortical tumors. J Clin Endocrinol Metab 97, E1004-1013.

Reisch, N., Rottenkolber, M., Greifenstein, A., Krone, N., Schmidt, H., Reincke, M., Schwarz, H.P., and Beuschlein, F. (2013). Testicular adrenal rest tumors develop independently of long-term disease control: A longitudinal analysis of 50 adult men with congenital adrenal hyperplasia due to classic 21hydroxylase deficiency. J Clin Endocrinol Metab 98, E1820-826.

Ritz-Laser, B., Mamin, A., Brun, T., Avril, I., Schwitzgebel, V.M., and Philippe, J. (2005). The zinc finger-containing transcription factor Gata-4 is expressed in the developing endocrine pancreas and activates glucagon gene expression. Mol Endocrinol 19, 759-770.

Robert, N.M., Tremblay, J.J., and Viger, R.S. (2002). Friend of GATA (FOG)-1 and FOG-2 differentially repress the GATA-dependent activity of multiple gonadal promoters. Endocrinology 143, 3963-3973.

Röhrig, T., Pihlajoki, M., Ziegler, R., Cochran, R.S., Schrade, A., Schillebeeckx, M., Mitra, R.D., Heikinheimo, M., and Wilson, D.B. (2014). Toying with fate: Redirecting the differentiation of adrenocortical progenitor cells into gonadal-like tissue. Mol Cell Endocrinol, Dec 8. doi: 10.1016/j.mce.2014.12.003.

Rosas, M., Davies, L.C., Giles, P.J., Liao, C.T., Kharfan, B., Stone, T.C., O'Donnell, V.B., Fraser, D.J., Jones, S.A., and Taylor, P.R. (2014). The transcription factor Gata6 links tissue macrophage phenotype and proliferative renewal. Science 344, 645-648. 
1062

1063

1064

1065

1066

1067

1068

1069

1070

1071

1072

1073

1074

1075

1076

1077

1078

1079
Sahut-Barnola, I., de Joussineau, C., Val, P., Lambert-Langlais, S., Damon, C., Lefrancois-Martinez, A.M., Pointud, J.C., Marceau, G., Sapin, V., Tissier, F., et al. (2010). Cushing's syndrome and fetal features resurgence in adrenal cortex-specific Prkar1a knockout mice. PLoS Genet 6, e1000980.

Sartori, D.J., Wilbur, C.J., Long, S.Y., Rankin, M.M., Li, C., Bradfield, J.P., Hakonarson, H., Grant, S.F., Pu, W.T., and Kushner, J.A. (2014). GATA factors promote ER integrity and beta-cell survival and contribute to type 1 diabetes risk. Mol Endocrinol 28, 28-39.

Schang, A.L., Granger, A., Querat, B., Bleux, C., Cohen-Tannoudji, J., and Laverriere, J.N. (2013). GATA2-induced silencing and LIM-homeodomain protein-induced activation are mediated by a bifunctional response element in the rat GnRH receptor gene. Mol Endocrinol 27, 74-91.

Schillebeeckx, M., Pihlajoki, M., Gretzinger, E., Yang, W., Thol, F., Hiller, T., Löbs, A.-K., Röhrig, T., Schrade, A., Cochran, R., et al. (2015). Novel markers of gonadectomy-induced adrenocortical neoplasia. Mol Cell Endocrinol 399, 122-130.

Schmidt, D., Ovitt, C.E., Anlag, K., Fehsenfeld, S., Gredsted, L., Treier, A.C., and Treier, M. (2004). The murine winged-helix transcription factor Fox12 is required for granulosa cell differentiation and ovary maintenance. Development 131, 933-942.

Schrade, A., Kyronlahti, A., Akinrinade, O., Pihlajoki, M., Hakkinen, M., Fischer, S., Alastalo, T.P., Velagapudi, V., Toppari, J., Wilson, D.B., et al. (2015). GATA4 is a key regulator of steroidogenesis and glycolysis in mouse Leydig cells. Endocrinology, 156, 1860-1872.

Schultz, K.A., Yang, J., Doros, L., Williams, G.M., Harris, A., Stewart, D.R., Messinger, Y., Field, A., Dehner, L.P., and Hill, D.A. (2014). DICER1-pleuropulmonary blastoma familial tumor predisposition syndrome: a unique constellation of neoplastic conditions. Pathol Case Rev 19, 90-100.

Schumer, S.T., and Cannistra, S.A. (2003). Granulosa cell tumor of the ovary. J Clin Oncol 21, 11801189.

Scully, K.M., and Rosenfeld, M.G. (2002). Pituitary development: regulatory codes in mammalian organogenesis. Science 295, 2231-2235.

Serewko-Auret, M.M., Mould, A.W., Loffler, K.A., Duncan, R., Kay, G.F., and Hayward, N.K. (2010). Alterations in gene expression in MEN1-associated insulinoma development. Pancreas 39, 11401146.

Shah, S.P., Kobel, M., Senz, J., Morin, R.D., Clarke, B.A., Wiegand, K.C., Leung, G., Zayed, A., Mehl, E., Kalloger, S.E., et al. (2009). Mutation of FOXL2 in granulosa-cell tumors of the ovary. N Engl J Med 360, 2719-2729.

Shaw-Smith, C., De Franco, E., Lango Allen, H., Batlle, M., Flanagan, S.E., Borowiec, M., Taplin, C.E., van Alfen-van der Velden, J., Cruz-Rojo, J., Perez de Nanclares, G., et al. (2014). GATA4 mutations are a cause of neonatal and childhood-onset diabetes. Diabetes 63, 2888-2894.

Shi, L.M., Tao, J.W., Qiu, X.B., Wang, J., Yuan, F., Xu, L., Liu, H., Li, R.G., Xu, Y.J., Wang, Q., et al. (2014). GATA5 loss-of-function mutations associated with congenital bicuspid aortic valve. Int J Mol Med 33, 1219-1226.

Siltanen, S., Anttonen, M., Heikkil, Narita, N., Laitinen, M., Ritvos, O., Wilson, D.B., and Heikinheimo, M. (1999). Transcription factor GATA-4 is expressed in pediatric yolk sac tumors. Am J Pathol 155, 1823-1829.

Smeets, E.E., Span, P.N., van Herwaarden, A.E., Wevers, R.A., Hermus, A.R., Sweep, F.C., and Claahsen-van der Grinten, H.L. (2015). Molecular characterization of testicular adrenal rest tumors in congenital adrenal hyperplasia: lesions with both adrenocortical and Leydig cell features. J Clin Endocrinol Metab 100, E524-530.

Spinner, M.A., Sanchez, L.A., Hsu, A.P., Shaw, P.A., Zerbe, C.S., Calvo, K.R., Arthur, D.C., Gu, W., Gould, C.M., Brewer, C.C., et al. (2014). GATA2 deficiency: a protean disorder of hematopoiesis, lymphatics, and immunity. Blood 123, 809-821.

Steger, D.J., Hecht, J.H., and Mellon, P.L. (1994). GATA-binding proteins regulate the human gonadotropin alpha-subunit gene in the placenta and pituitary gland. Mol Cell Biol 14, 5592-5602.

Tevosian, S. (2014). Transgenic mouse models in the study of reproduction: insight into GATA protein function. Reproduction 148, R1-R14. 
1080

1081

1082

1083

1084

1085

1086

1087

1088

1089

1090

1091

1092

1093

1094

1095

1096

1097

1098

1099

1100

1101

1102

1103

1104

1105

1106

1107

1108

1109

1110

1111

1112

1113

1114

1115

1116

1117

1118

1119

1120

1121

1122

1123

1124

1125

1126

1127

1128

1129
Tevosian, S.G., Albrecht, K.H., Crispino, J.D., Fujiwara, Y., Eicher, E.M., and Orkin, S.H. (2002). Gonadal differentiation, sex determination and normal Sry expression in mice require direct interaction between transcription partners GATA4 and FOG2. Development 129, 4627-4634.

Tian, Y., Zhang, Y., Hurd, L., Hannenhalli, S., Liu, F., Lu, M.M., and Morrisey, E.E. (2011). Regulation of lung endoderm progenitor cell behavior by miR302/367. Development 138, 1235-1245.

Tissier, F., Cavard, C., Groussin, L., Perlemoine, K., Fumey, G., Hagnere, A.M., Rene-Corail, F., Jullian, E., Gicquel, C., Bertagna, X., et al. (2005). Mutations of beta-catenin in adrenocortical tumors: activation of the Wnt signaling pathway is a frequent event in both benign and malignant adrenocortical tumors. Cancer Res 65, 7622-7627.

Tremblay, J.J., and Viger, R.S. (2003). Transcription factor GATA-4 is activated by phosphorylation of serine 261 via the cAMP/protein kinase a signaling pathway in gonadal cells. J Biol Chem 278, 2212822135.

Tsuji, S., Kawasaki, Y., Furukawa, S., Taniue, K., Hayashi, T., Okuno, M., Hiyoshi, M., Kitayama, J., and Akiyama, T. (2014). The miR-363-GATA6-Lgr5 pathway is critical for colorectal tumourigenesis. Nat Commun 5, 3150.

Tsuji, T., Catasus, L., and Prat, J. (2005). Is loss of heterozygosity at 9q22.3 (PTCH gene) and 19p13.3 (STK11 gene) involved in the pathogenesis of ovarian stromal tumors? Hum Pathol 36, 792-796.

Ueda, M., Kanematsu, A., Nishiyama, H., Yoshimura, K., Watanabe, K., Yorifuji, T., Mikami, Y., Kamoto, T., and Ogawa, O. (2010). Testicular thecoma in an 11-year-old boy with nevoid basal-cell carcinoma syndrome (Gorlin syndrome). J Pediatr Surg 45, E1-3.

Uhlenhaut, N.H., Jakob, S., Anlag, K., Eisenberger, T., Sekido, R., Kress, J., Treier, A.C., Klugmann, C., Klasen, C., Holter, N.I., et al. (2009). Somatic sex reprogramming of adult ovaries to testes by FOXL2 ablation. Cell 139, 1130-1142.

Umeoka, K., Sanno, N., Osamura, R.Y., and Teramoto, A. (2002). Expression of GATA-2 in human pituitary adenomas. Mod Pathol 15, 11-17.

Val, P., Jeays-Ward, K., and Swain, A. (2006). Identification of a novel population of adrenal-like cells in the mammalian testis. Dev Biol 299, 250-256.

Van Esch, H., Groenen, P., Nesbit, M.A., Schuffenhauer, S., Lichtner, P., Vanderlinden, G., Harding, B., Beetz, R., Bilous, R.W., Holdaway, I., et al. (2000). GATA3 haplo-insufficiency causes human HDR syndrome. Nature 406, 419-422.

Viger, R.S., Guittot, S.M., Anttonen, M., Wilson, D.B., and Heikinheimo, M. (2008). Role of the GATA family of transcription factors in endocrine development, function, and disease. Mol Endocrinol 22, 781-798.

Virgone, C., Cecchetto, G., Ferrari, A., Bisogno, G., Donofrio, V., Boldrini, R., Collini, P., Dall'Igna, P., and Alaggio, R. (2012). GATA-4 and FOG-2 expression in pediatric ovarian sex cord-stromal tumors replicates embryonal gonadal phenotype: results from the TREP project. PLoS One 7, e45914.

Wang, E.L., Qian, Z.R., Yamada, S., Rahman, M.M., Inosita, N., Kageji, T., Endo, H., Kudo, E., and Sano, T. (2009). Clinicopathological characterization of TSH-producing adenomas: special reference to TSH-immunoreactive but clinically non-functioning adenomas. Endocr Pathol 20, 209-220.

Watt, A.J., Zhao, R., Li, J., and Duncan, S.A. (2007). Development of the mammalian liver and ventral pancreas is dependent on GATA4. BMC Dev Biol 7, 37.

Whissell, G., Montagni, E., Martinelli, P., Hernando-Momblona, X., Sevillano, M., Jung, P., Cortina, C., Calon, A., Abuli, A., Castells, A., et al. (2014). The transcription factor GATA6 enables self-renewal of colon adenoma stem cells by repressing BMP gene expression. Nat Cell Biol 16, 695-707.

Witkowski, L., Mattina, J., Schonberger, S., Murray, M.J., Choong, C.S., Huntsman, D.G., Reis-Filho, J.S., McCluggage, W.G., Nicholson, J.C., Coleman, N., et al. (2013). DICER1 hotspot mutations in nonepithelial gonadal tumours. Br J Cancer 109, 2744-2750.

Wu, D., Sunkel, B., Chen, Z., Liu, X., Ye, Z., Li, Q., Grenade, C., Ke, J., Zhang, C., Chen, H., et al. (2014). Three-tiered role of the pioneer factor GATA2 in promoting androgen-dependent gene expression in prostate cancer. Nucleic Acids Res 42, 3607-3622. 
Xuan, S., Borok, M.J., Decker, K.J., Battle, M.A., Duncan, S.A., Hale, M.A., Macdonald, R.J., and Sussel, L. (2012). Pancreas-specific deletion of mouse Gata4 and Gata6 causes pancreatic agenesis. J Clin Invest 122, 3516-3528.

Yomogida, K., Ohtani, H., Harigae, H., Ito, E., Nishimune, Y., Engel, J.D., and Yamamoto, M. (1994). Developmental stage- and spermatogenic cycle-specific expression of transcription factor GATA-1 in mouse Sertoli cells. Devel 120, 1759-1766.

Yorifuji, T., Kawakita, R., Hosokawa, Y., Fujimaru, R., Yamaguchi, E., and Tamagawa, N. (2012). Dominantly inherited diabetes mellitus caused by GATA6 haploinsufficiency: variable intrafamilial presentation. J Med Genet 49, 642-643.

Yu, L., Bennett, J.T., Wynn, J., Carvill, G.L., Cheung, Y.H., Shen, Y., Mychaliska, G.B., Azarow, K.S., Crombleholme, T.M., Chung, D.H., et al. (2014). Whole exome sequencing identifies de novo mutations in GATA6 associated with congenital diaphragmatic hernia. J Med Genet 51, 197-202.

Yu, L., Wynn, J., Cheung, Y.H., Shen, Y., Mychaliska, G.B., Crombleholme, T.M., Azarow, K.S., Lim, F.Y., Chung, D.H., Potoka, D., et al. (2013). Variants in GATA4 are a rare cause of familial and sporadic congenital diaphragmatic hernia. Hum Genet 132, 285-292.

Zanotti, K.M. (2002). The clinical manifestations and diagnosis of Sertoli-Leydig cell tumors of the ovary. CME Journal of Gynecologic Oncology 7, 129-133.

Zhang, H.Y., Zhu, J.E., Huang, W., and Zhu, J. (2014). Clinicopathologic features of ovarian SertoliLeydig cell tumors. Int J Clin Exp Pathol 7, 6956-6964.

Zhang, Y., Goss, A.M., Cohen, E.D., Kadzik, R., Lepore, J.J., Muthukumaraswamy, K., Yang, J., DeMayo, F.J., Whitsett, J.A., Parmacek, M.S., et al. (2008). A Gata6-Wnt pathway required for epithelial stem cell development and airway regeneration. Nat Genet 40, 862-870.

Zheng, R., and Blobel, G.A. (2010). GATA transcription factors and cancer. Genes Cancer 1, 11781188.

Zhong, Y., Wang, Z., Fu, B., Pan, F., Yachida, S., Dhara, M., Albesiano, E., Li, L., Naito, Y., Vilardell, F., et al. (2011). GATA6 activates Wnt signaling in pancreatic cancer by negatively regulating the Wnt antagonist Dickkopf-1. PLoS One 6, e22129. 
1159 Table 1. Human diseases associated with germline loss-of-function mutations in GATA factors

\begin{tabular}{|c|c|c|}
\hline Gene & Human disease phenotype & References \\
\hline GATAl & $\begin{array}{l}\text { - X-linked dyserythropoietic anemia and thrombocytopenia } \\
\text { - X-linked Diamond-Blackfan anemia }\end{array}$ & $\begin{array}{l}\text { (Crispino and } \\
\text { Weiss, 2014) }\end{array}$ \\
\hline GATA2 & 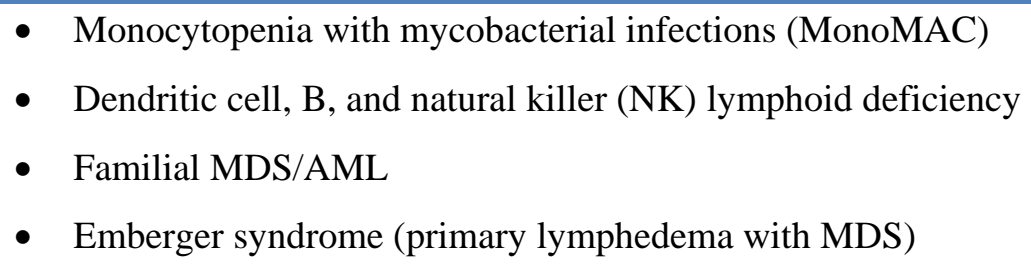 & $\begin{array}{l}\text { (Bresnick et al., } \\
\text { 2012; Spinner et al., } \\
\text { 2014) }\end{array}$ \\
\hline GATA3 & $\begin{array}{l}\text { - HDR syndrome (hypoparathyroidism, deafness, and renal } \\
\text { dysplasia) }\end{array}$ & $\begin{array}{l}\text { (Ali et al., 2007; } \\
\text { Nesbit et al., 2004; } \\
\text { Van Esch et al., } \\
\text { 2000) }\end{array}$ \\
\hline GATA4 & $\begin{array}{l}\text { - } \text { Congential heart disease } \\
\text { - } \text { Congenital diaphragmatic hernia } \\
\text { - } \text { Monogenic diabetes } \\
\text { - }\end{array}$ & $\begin{array}{l}\text { (Lourenco et al., } \\
\text { 2011; Prendiville et } \\
\text { al., 2014; Shaw- } \\
\text { Smith et al., 2014; } \\
\text { Yu et al., 2013) }\end{array}$ \\
\hline GATA5 & - Congential heart disease & (Shi et al., 2014) \\
\hline GATA6 & $\begin{array}{l}\text { - } \text { Congenital heart disease } \\
\text { - Pancreatic agenesis and/or monogenic diabetes } \\
\text { - } \text { Biliary tract abnormalities } \\
\text { - } \quad \text { Congenital diaphragmatic hernia }\end{array}$ & $\begin{array}{l}\text { (Allen et al., 2012; } \\
\text { Bonnefond et al., } \\
\text { 2012; Maitra et al., } \\
\text { 2010; Prendiville et } \\
\text { al., 2014; Yu et al., } \\
\text { 2014) }\end{array}$ \\
\hline
\end{tabular}


Table 2. Ovarian phenotypes of Gata4 and Gata6 conditional knockout mice

\begin{tabular}{|l|l|l|l|}
\hline \multirow{3}{*}{ Gata4 } & Sfl-cre & $\begin{array}{l}\text { Impaired granulosa/theca cell proliferation, depletion } \\
\text { of primordial follicles, ovarian cyst formation, and } \\
\text { sterility }\end{array}$ & $\begin{array}{l}\text { (Efimenko et al., } \\
\text { 2013) }\end{array}$ \\
\cline { 2 - 4 } & Amhr2-cre & $\begin{array}{l}\text { Cystic ovarian changes, impaired fertility, and a } \\
\text { blunted response to exogenous gonadotropins }\end{array}$ & $\begin{array}{l}\text { (Kyrönlahti et } \\
\text { al., 2011b) }\end{array}$ \\
\hline \multirow{2}{*}{ Gata6 } & Sfl-cre & No overt phenotype & $\begin{array}{l}\text { (Pihlajoki et al., } \\
\text { 2013) }\end{array}$ \\
\cline { 2 - 5 } & Amhr2-cre & $\begin{array}{l}\text { Early embryonic lethal owing to leaky expression in } \\
\text { yolk sac endoderm }\end{array}$ & $\begin{array}{l}\text { Wilson, } \\
\text { unpublished } \\
\text { observations }\end{array}$ \\
\hline \multirow{2}{*}{ Gata6 } & Cyp19-cre & $\begin{array}{l}\text { Impaired formation of large pre-ovulatory follicles and } \\
\text { corpora lutea, an abnormal estrous cycle, and } \\
\text { infertility; impaired expression of Fshr, Lhcgr, Inha, } \\
\text { and Inhbb) }\end{array}$ & $\begin{array}{l}\text { (Bennett et al., } \\
\text { 2013; Bennett et } \\
\text { al., 2012) }\end{array}$ \\
\cline { 2 - 4 } & Sfl-cre & $\begin{array}{l}\text { Aberrant folliculogenesis and impaired expression of } \\
\text { genes involved in early ovarian development, including } \\
\text { Foxl2 and Fst }\end{array}$ & $\begin{array}{l}\text { (Padua et al., } \\
\text { 2014) }\end{array}$ \\
\hline
\end{tabular}


1168 Table 3. Genetically-engineered mouse models of GCT

\begin{tabular}{|c|c|c|c|}
\hline \multicolumn{2}{|l|}{ Genotype } & \multirow{2}{*}{$\begin{array}{l}\text { Tumor } \\
\text { penetrance } \\
(\%) \\
100\end{array}$} & \multirow{2}{*}{$\begin{array}{l}\text { References } \\
\text { (Kananen et } \\
\text { al., 1995) }\end{array}$} \\
\hline Inha-TAg & $\begin{array}{l}\text { Infertile, GCT formation at age of } \\
5-7 \text { mo, serum inhibin B } \uparrow \text {, serum } \\
\text { gonadotropins } \downarrow\end{array}$ & & \\
\hline Inha $a^{-/}$ & $\begin{array}{l}\text { Bilateral, mixed, or incompletely } \\
\text { differentiated sex cord-stromal } \\
\text { tumors coupled with cachexia-like } \\
\text { syndrome at age of } 4 \mathrm{wks}\end{array}$ & 100 & $\begin{array}{l}\text { (Matzuk et } \\
\text { al., 1992) }\end{array}$ \\
\hline $\begin{array}{l}\text { Smadl/5 double } \\
\text { knockout }\end{array}$ & $\begin{array}{l}\text { Infertile, poorly differentiated, } \\
\text { metastatic, uni- or bilateral GCT at } \\
\text { age of } 3 \text { mo, histopathological } \\
\text { features similar to human juvenile } \\
\text { GCT }\end{array}$ & 100 & $\begin{array}{l}\text { (Pangas et } \\
\text { al., 2008) } \\
\text { (Middlebrook } \\
\text { et al., 2009) }\end{array}$ \\
\hline $\begin{array}{l}\text { Smad1/5/8 triple } \\
\text { knockout }\end{array}$ & $\begin{array}{l}\text { Infertile, poorly differentiated, } \\
\text { metastatic, uni- or bilateral GCT at } \\
\text { age of } 3 \mathrm{mo}\end{array}$ & 100 & $\begin{array}{l}\text { (Pangas et } \\
\text { al., 2008) }\end{array}$ \\
\hline $\begin{array}{l}\text { Catnb }^{\text {flox }(e x 3) /+} \\
\text { Amhr2 } \\
\text { cre/+ }\end{array}$ & $\begin{array}{l}\text { Subfertile, follicle-like lesions that } \\
\text { evolve into GCT at } 7.5 \mathrm{mo} \text { of age }\end{array}$ & 57 & $\begin{array}{l}\text { (Boerboom et } \\
\text { al., 2005) }\end{array}$ \\
\hline $\mathrm{MenI}^{+/-}$ & $\begin{array}{l}\text { Develop GCTs, a feature not typical } \\
\text { of humans with the MEN1 cancer } \\
\text { predisposition syndrome; Gata6 is } \\
\text { downregulated in GCTs that arise in } \\
\text { the ovaries of these mice }\end{array}$ & 70 & $\begin{array}{l}\text { (Mould et al., } \\
\text { 2009) }\end{array}$ \\
\hline
\end{tabular}


Table 4. Testicular phenotypes of Gata4 and Gata6 conditional knockout mice

1172

\begin{tabular}{|c|c|c|c|}
\hline Gene(s) & Cre & Phenotype & References \\
\hline \multirow[t]{4}{*}{ Gata4 } & Sfl-cre & Decreased expression of Dmrt 1 ; germ cell attrition & $\begin{array}{l}\text { (Manuylov et al., } \\
\text { 2011) }\end{array}$ \\
\hline & Amhr2-cre & $\begin{array}{l}\text { Late onset impairment of Sertoli cell function with } \\
\text { loss of fertility }\end{array}$ & $\begin{array}{l}\text { (Kyrönlahti et al., } \\
\text { 2011b) }\end{array}$ \\
\hline & Wt1-creERT2 & $\begin{array}{l}\text { Conditional ablation at E10.5 leads to a block in } \\
\text { testicular differentiation and male-to-female sex } \\
\text { reversal }\end{array}$ & $\begin{array}{l}\text { (Manuylov et al., } \\
\text { 2011) }\end{array}$ \\
\hline & $C A G$-creER & $\begin{array}{l}\text { Impaired formation of the genital ridge and } \\
\text { subsequent licensing of primordial germ cells }\end{array}$ & $\begin{array}{l}\text { (Hu et al., 2015; } \\
\text { Hu et al., 2013) }\end{array}$ \\
\hline \multirow[t]{2}{*}{ Gata6 } & Sfl-cre & No overt phenotype & $\begin{array}{l}\text { (Pihlajoki et al., } \\
\text { 2013) }\end{array}$ \\
\hline & Amhr2-cre & $\begin{array}{l}\text { Early embryonic lethal owing to leaky expression } \\
\text { in yolk sac endoderm }\end{array}$ & $\begin{array}{l}\text { Wilson, } \\
\text { unpublished } \\
\text { observations }\end{array}$ \\
\hline $\begin{array}{l}\text { Gata4 \& } \\
\text { Gata6 }\end{array}$ & Sfl-cre & $\begin{array}{l}\text { Impaired spermatogenesis, absence of Leydig cells, } \\
\text { and ectopic appearance of adrenocortical-like cells }\end{array}$ & $\begin{array}{l}\text { (Padua et al., } \\
\text { 2015) }\end{array}$ \\
\hline
\end{tabular}


Table 5. GATA factors in endocrine cell types and their corresponding neoplasms

\begin{tabular}{|c|c|c|c|}
\hline Tissue & GATA factor & Cell type & Tumor \\
\hline \multirow[t]{2}{*}{ Ovary } & GATA4 & $\begin{array}{l}\text { Granulosa cells } \\
\text { Theca cells }\end{array}$ & $\begin{array}{l}\text { Human: } \\
\text { AGCT, SLCT, } \\
\text { thecoma-fibroma }\end{array}$ \\
\hline & GATA6 & $\begin{array}{l}\text { Granulosa cells } \\
\text { Theca cells } \\
\text { Corpus luteum }\end{array}$ & \\
\hline \multirow[t]{3}{*}{ Testis } & GATA1 & Sertoli cell & \\
\hline & GATA4 & $\begin{array}{l}\text { Sertoli cells } \\
\text { Leydig cells } \\
\text { Peritubular cells }\end{array}$ & $\begin{array}{l}\text { Human: } \\
\text { LCCSCT } \\
\text { Canine: } \\
\text { SCT, LCT, MGSCT }\end{array}$ \\
\hline & GATA6 & $\begin{array}{l}\text { Sertoli cells } \\
\text { Leydig cells }\end{array}$ & \\
\hline \multirow[t]{4}{*}{ Adrenal cortex } & GATA4 & Fetal cortex & $\begin{array}{l}\text { Mouse, ferret: } \\
\text { GDX-induced } \\
\text { neoplasms }\end{array}$ \\
\hline & & & $\begin{array}{l}\text { Mouse: } \\
\text { Inh } \alpha \text {-Tag and Inha }{ }^{-/-} \\
\text {gonadal-like tumors }\end{array}$ \\
\hline & & & $\begin{array}{l}\text { Human: } \\
\text { Minority of } \\
\text { adenomas and } \\
\text { carcinomas }\end{array}$ \\
\hline & GATA6 & $\begin{array}{l}\text { Mouse: } \\
\text { Fetal cortex } \\
\text { Adult (sub)capsule } \\
\text { Human: } \\
\text { Fetal cortex } \\
\text { zR }\end{array}$ & $\begin{array}{l}\text { Human: } \\
\text { Majority of } \\
\text { adenomas, } \\
\text { carcinomas }\end{array}$ \\
\hline Parathyroid gland & GATA3 & Parathyroid cells & $\begin{array}{l}\text { Human: } \\
\text { Adenomas and } \\
\text { carcinomas }\end{array}$ \\
\hline \multirow[t]{2}{*}{ Pancreas } & GATA4 & $\begin{array}{l}\text { Multipotential } \\
\text { progenitor cells } \\
\text { Acinar cells }\end{array}$ & $\begin{array}{l}\text { Human: } \\
\text { Pancreatic ductul } \\
\text { adenocarcinoma }\end{array}$ \\
\hline & GATA6 & $\begin{array}{l}\text { Multipotential } \\
\text { progenitor cells } \\
\text { Islet cells }\end{array}$ & $\begin{array}{l}\text { Human: } \\
\text { Pancreatic ductul } \\
\text { adenocarcinoma }\end{array}$ \\
\hline Pituitary & GATA2 & $\begin{array}{l}\text { Gonadotrope cells } \\
\text { Thyrotrope cells }\end{array}$ & $\begin{array}{l}\text { Human: } \\
\text { adenomas }\end{array}$ \\
\hline
\end{tabular}

Abbreviations: AGCT, adult-type granulosa cell tumor; GDX, gonadectomy; LCCSCT, large-cell calcifying Sertoli tumor; LCT, Leydig (interstitial) cell tumor; MGSCT, mixed germ cell sex cord-stromal tumor; SCT; Sertoli cell tumor; SLCT, Sertoli-Leydig cell tumor; zR, zona reticularis. 


\section{Figure Legends}

Figure 1. Expression of Gata4 and Gata6 in developing mouse ovary. (A-D) Cryosections of E18.5 mouse were subjected to in situ hybridization for GATA4 or GATA6 using $\left[{ }^{33} \mathrm{P}\right]$-labelled riboprobes and counterstained with hematoxylin and eosin $(\mathrm{H} \& \mathrm{E})$. Shown are corresponding brightfield $(\mathrm{A}, \mathrm{B})$ and darkfield (C,D) photomicrographs. GATA4 and GATA6 mRNA are evident in fetal ovary (ov) and small intestine (si). Additionally, GATA6 mRNA is seen in the mesovarium (mo) but not in the Müllerian duct (md). Bars $=100 \mu \mathrm{m} .(\mathrm{E}, \mathrm{F})$ Immunoperoxidase staining of ovary from a parous female (P90) mouse. GATA4 and GATA6 protein are evident in granulosa cells $(\mathrm{gc})$ and germinal epithelium (ge). Bars $=50$ $\mu \mathrm{m}$.

\section{Figure 2. Interplay among GATA4, FOXL2, and SMAD3 during human granulosa cell tumor} development. Sections of formalin-fixed AGCT were subjected to immunoperoxidase staining for A) GATA4, B) FOXL2, and C) SMAD3. Bar $=50 \mu \mathrm{m}$. Normal granulosa cell growth is modulated by cooperative interactions among wild-type FOXL2, GATA4, and SMAD3 (D). The C134W mutation in FOXL2 disrupts this balance leading to malignant cell growth (E).

\section{Figure 3. Immunohistochemical staining of GATA4 in a human large cell calcifying Sertoli cell}

tumor. The box in panel A is shown at higher magnification in panel B. The asterisk highlights a calcified granule in the Sertoli cell tumor. Note that GATA4 is abundantly expressed in Sertoli (arrowheads) tumor cells. The adjacent normal Sertoli cells (open arrowheads) also express GATA4. Abbreviations: nl, normal seminiferous tubule; tu; tumor. Bar $=50 \mu \mathrm{m}$.

\section{Figure 4. Immunohistochemical staining of GATA4 in a GDX-induced adrenocortical carcinoma of}

the ferret. Serial sections of formalin-fixed tissue were stained with A) hematoxylin \& eosin, or B) GATA4 antibody, followed by hematoxylin counterstaining. Bar $=50 \mu \mathrm{m}$. 
1207 Figure 5. Immunohistochemical staining of GATA6 in human adrenocortical tumors.

1208 Representative samples of nonfunctional (Nonf), Conn's (aldosterone-producing), and Cushing's (cortisol-

1209 producing) adenomas (A, C, E, respectively) and carcinomas (B, D, F, respectively) are shown.

1210 Immunoreactive cells (arrowheads) exhibit brown nuclear staining. Sections were counterstained with

1211 hematoxylin. Bar $=50 \mu \mathrm{m}$.

1212

1213 Figure 6. Immunohistochemical staining of GATA4 and GATA6 in the developing mouse pancreas.

1214 Three developmental stages are illustrated: E15.5, newborn (postnatal day 1), and adult (3 months). The

1215 expression patterns reveal association of GATA4 (A, G, M) primarily with exocrine and GATA6 (B, H,

$1216 \mathrm{~N}$ ) with endocrine cells (arrows). Bar $=150 \mu \mathrm{m}$.

1217

1218 Figure 7. GATA4 immunostaining distinguishes normal exocrine pancreas from a well-

1219 encapsulated insulinoma of the ferret. Serial sections of formalin-fixed tissue were stained with A)

1220 hematoxylin \& eosin (H\&E), or B) GATA4 antibody, followed by hematoxylin counterstaining. Note that

1221 pancreatic acinar cells exhibit GATA4 immunoreactivity, whereas insulinoma cells do not. Bar $=50 \mu \mathrm{m}$. 

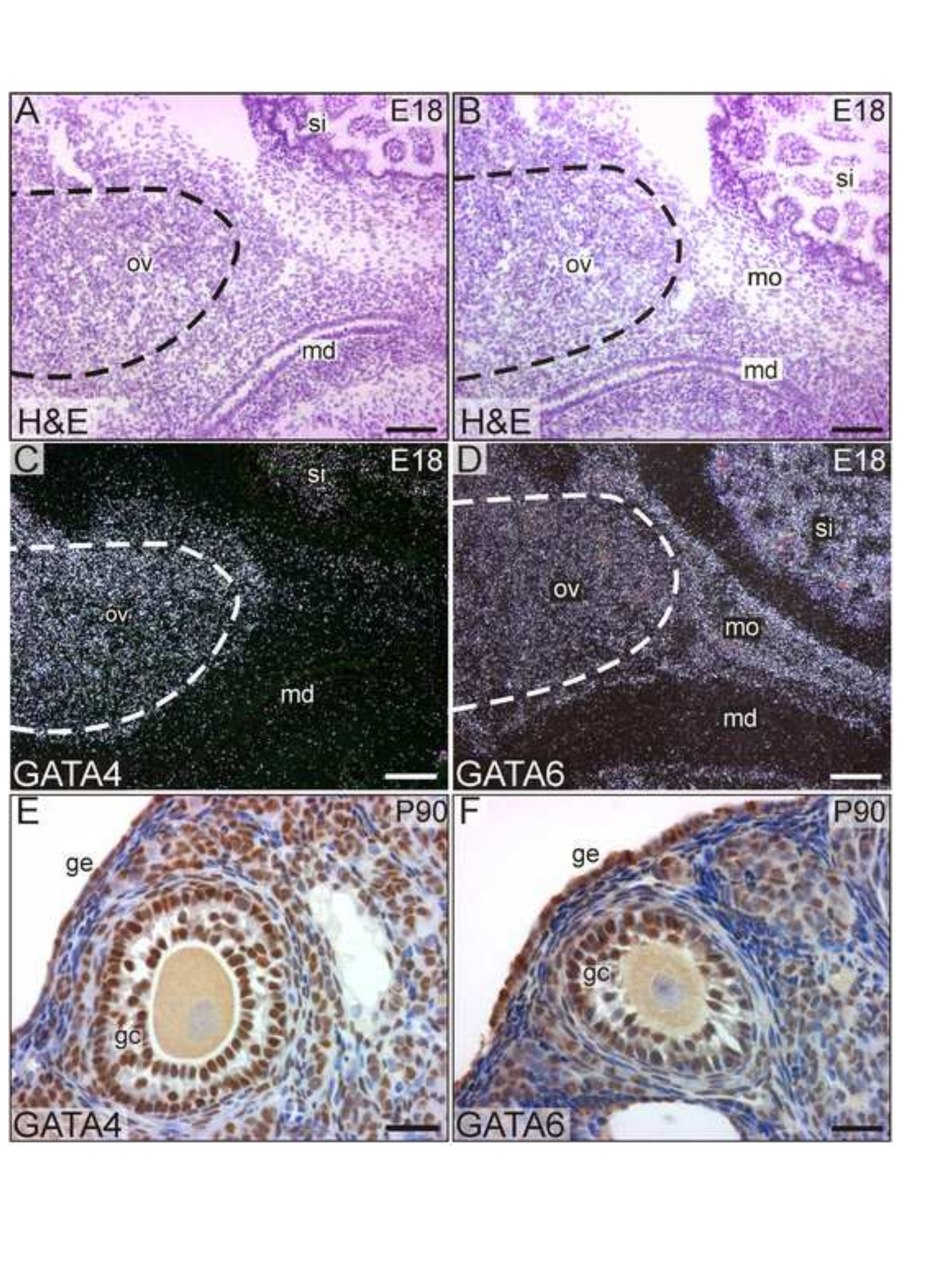

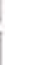

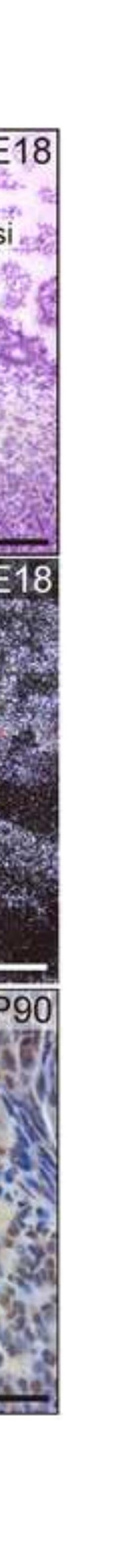




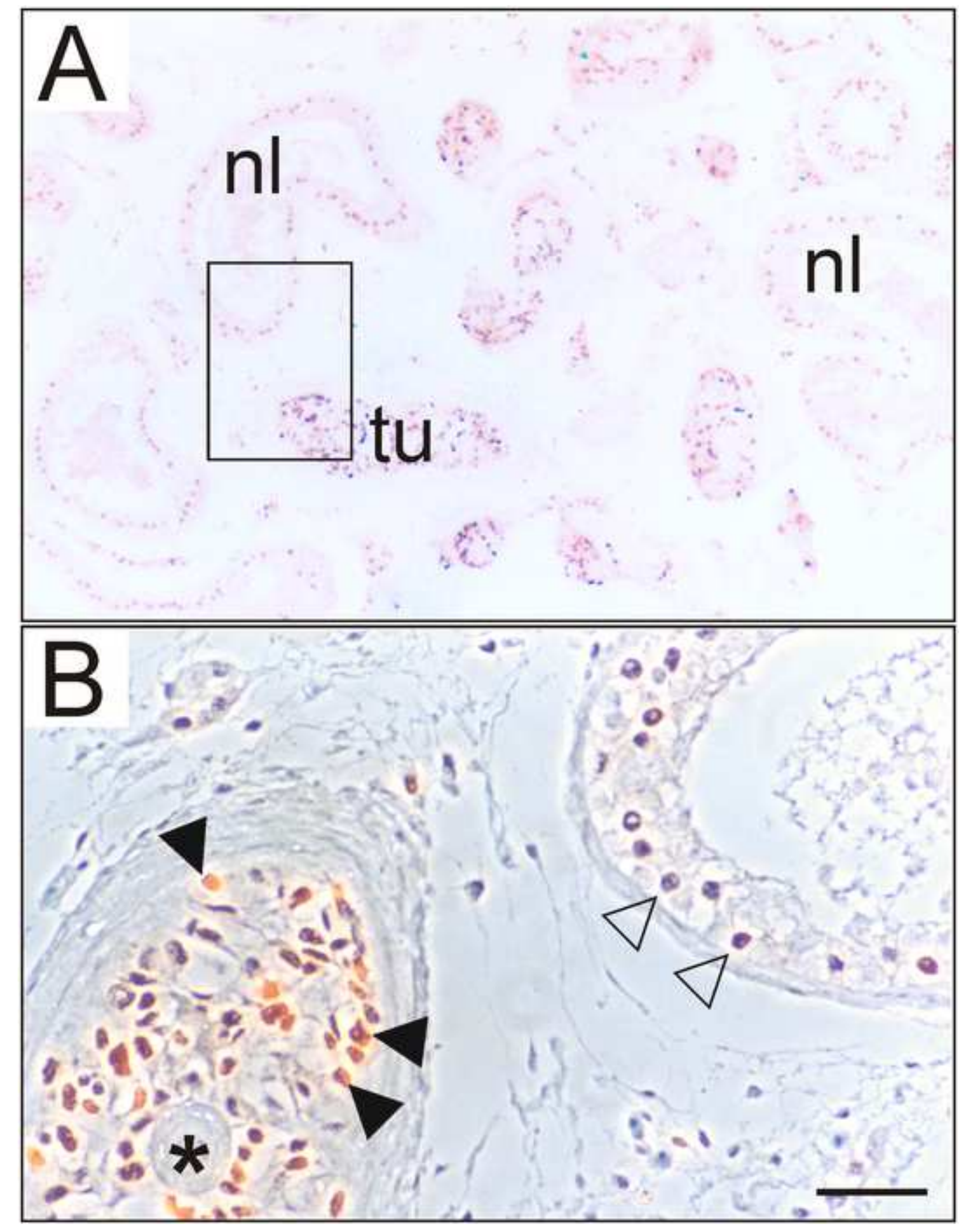

Figure 3

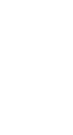



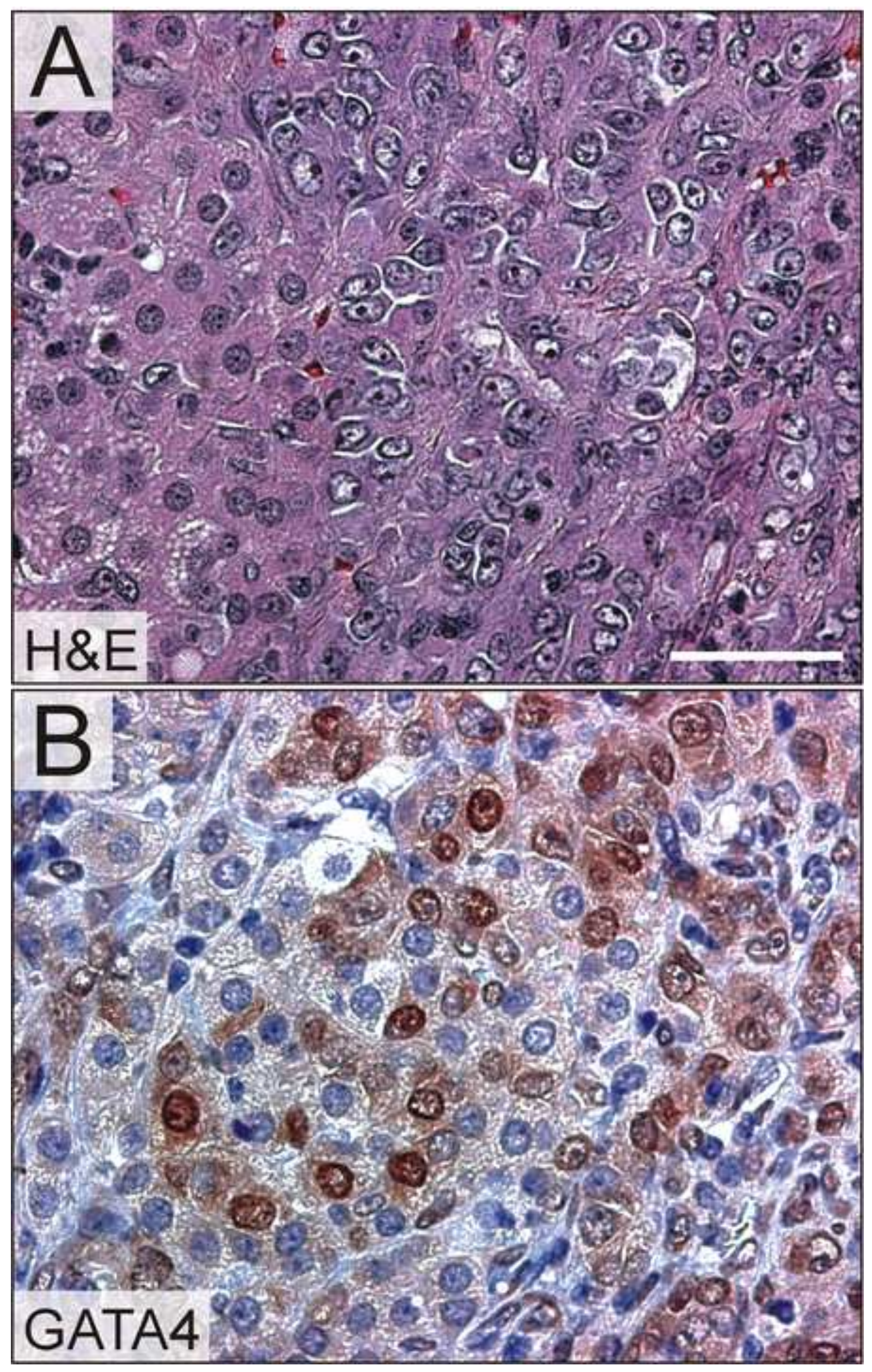

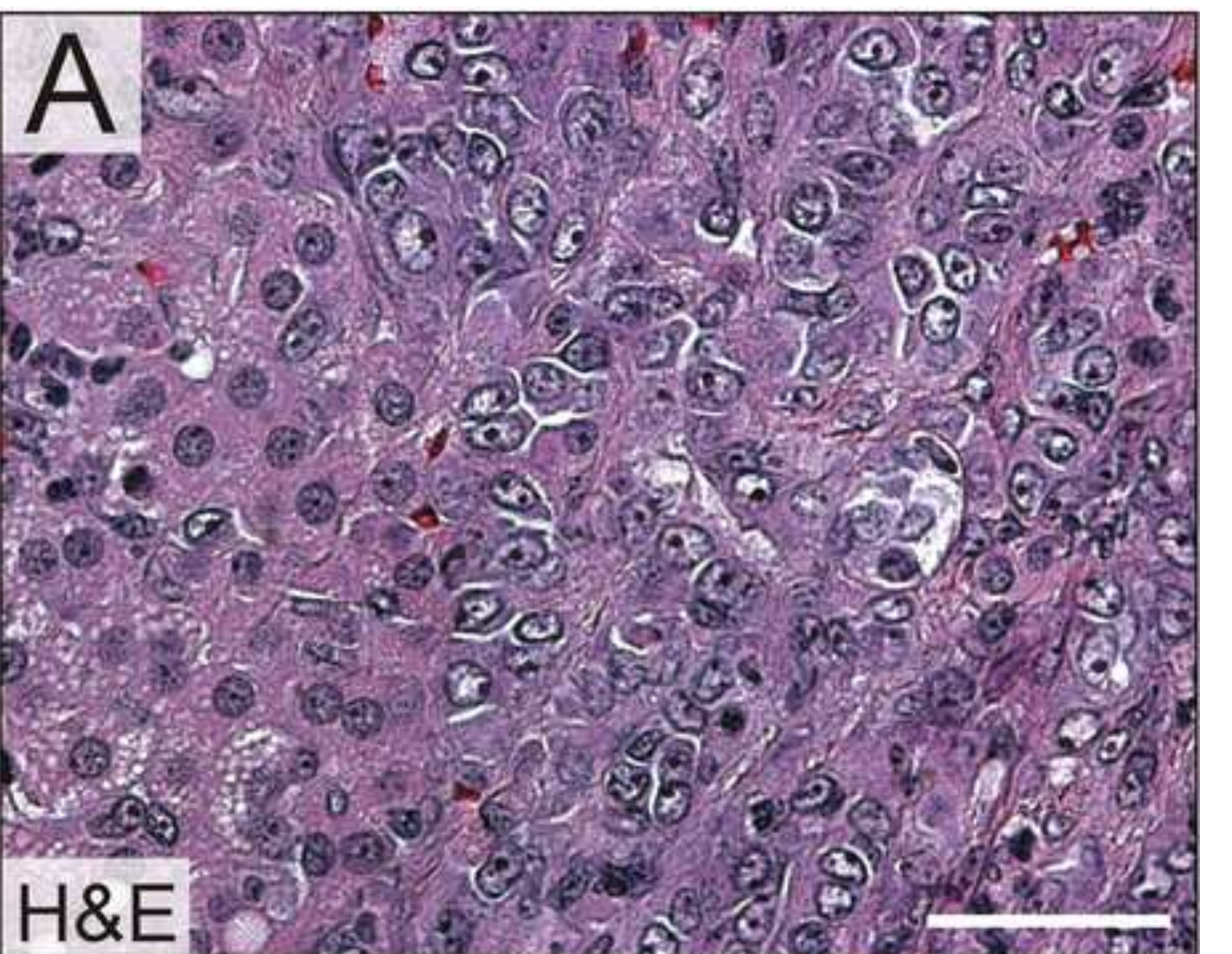

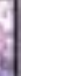

.




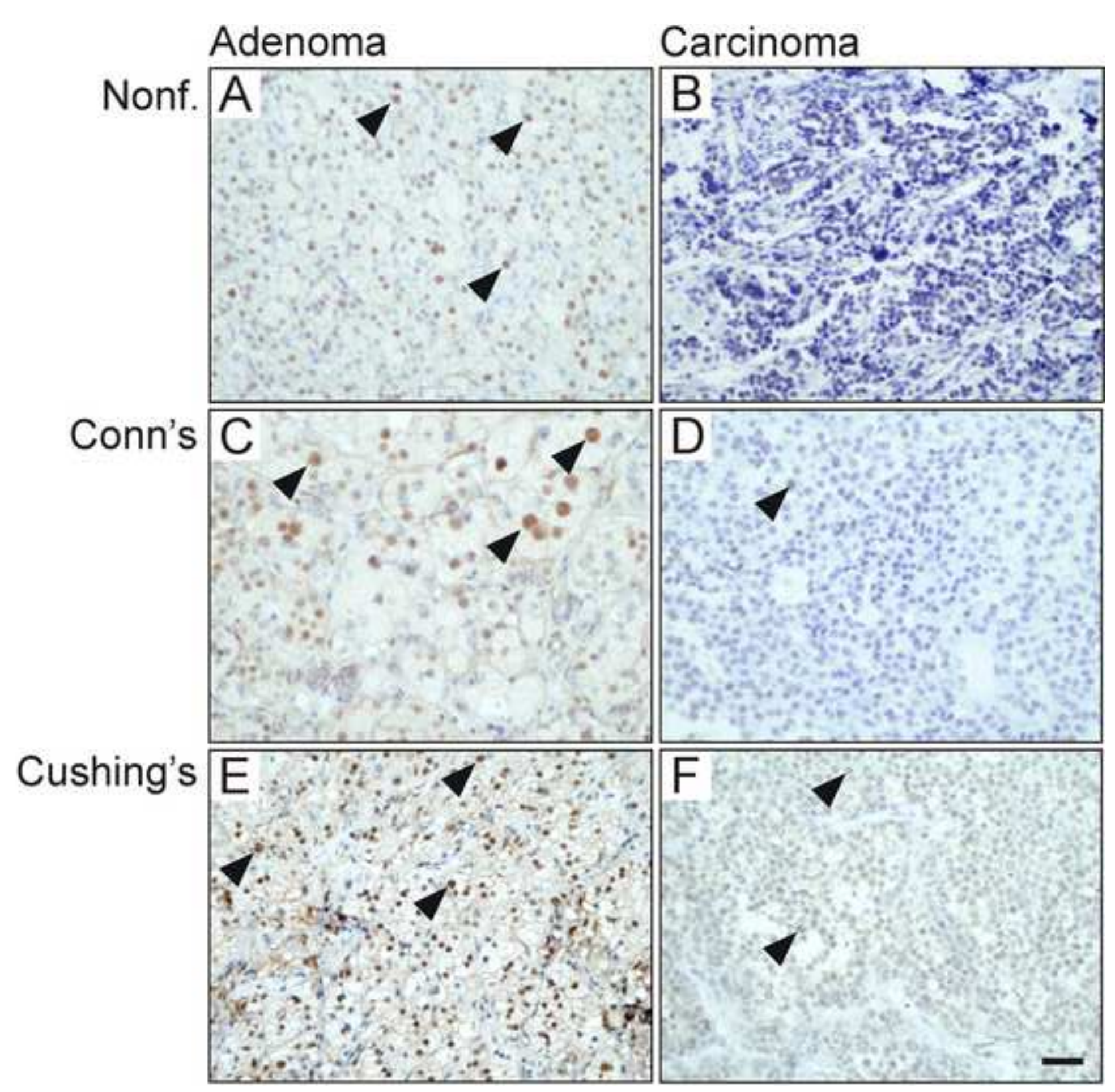




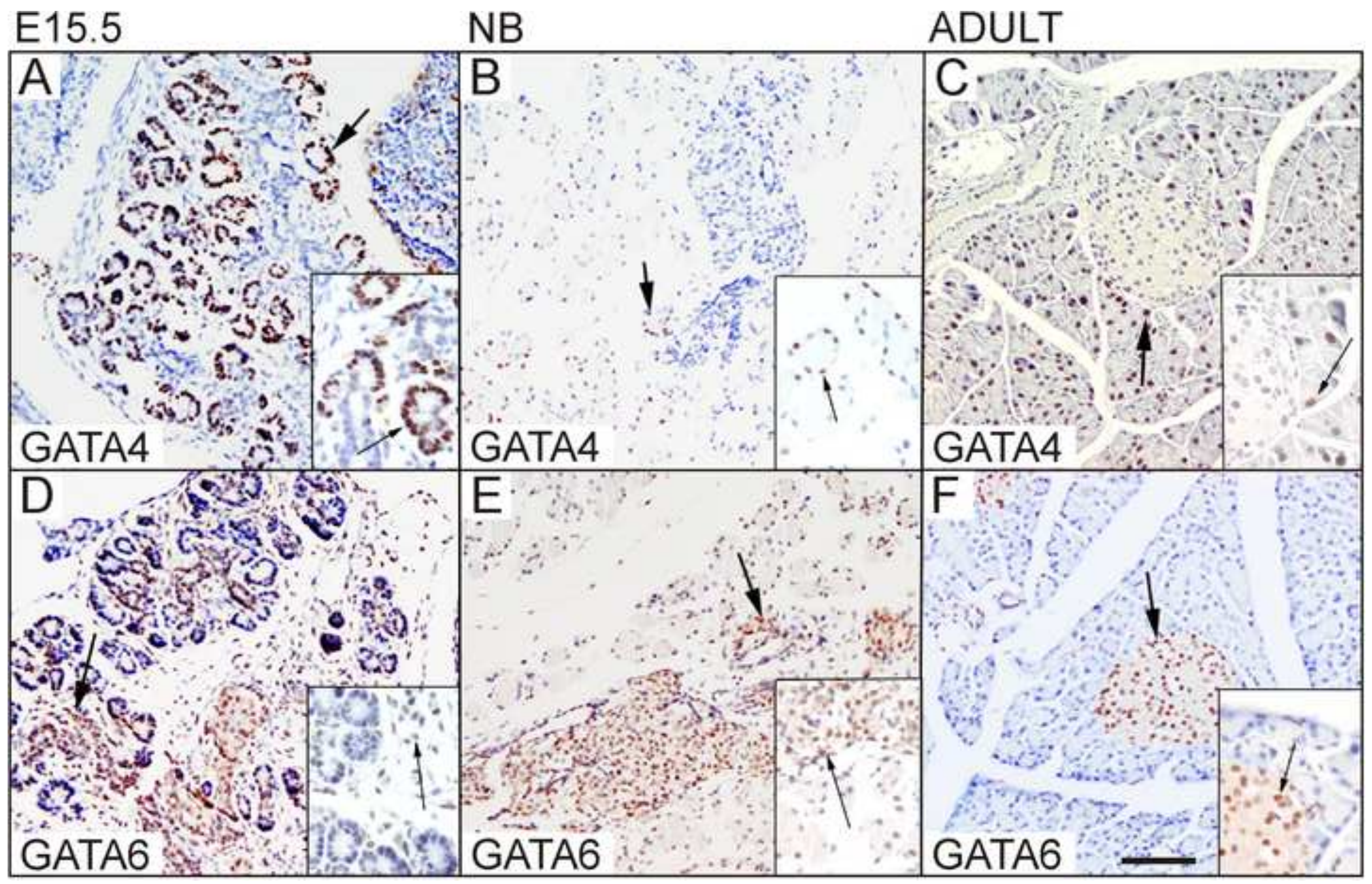




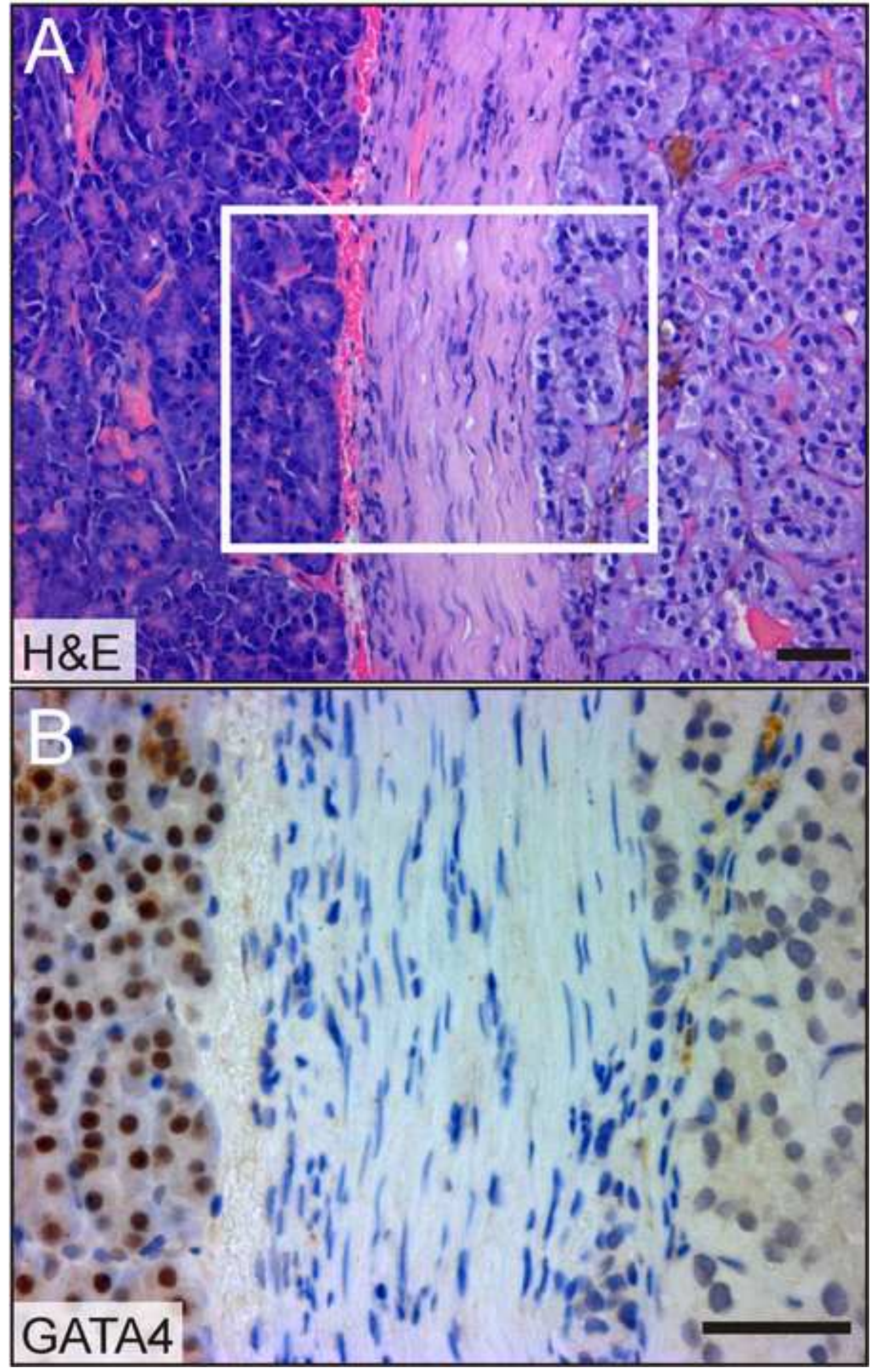

Figure

A

$$
\text { . }
$$

